\title{
ANALYZING THE IMPLEMENTATION OF ENVIRONMENTAL LAWS IN THE SAUDI ARABIAN CONSTRUCTION INDUSTRY
}

\author{
MANSOUR, M. A. A. ${ }^{1,2 *}-$ KHADAR, S. D. A. ${ }^{2}-$ FALQI, I. I. A. ${ }^{3}$ \\ ${ }^{1}$ Industrial Engineering Department, College of Engineering, Zagazig University \\ 44519 Zagazig, Egypt \\ ${ }^{2}$ Industrial Engineering Department, College of Engineering, King Khalid University \\ Abha, Saudi Arabia \\ (e-mail: shdawood@kku.edu.sa; phone: +966-54-852-0411-S. D. A. Khadar) \\ ${ }^{3}$ Civil Engineering Department, College of Engineering, King Khalid University \\ Abha, Saudi Arabia \\ (e-mail: ifalqi@kku.edu.sa; phone: +966-50-207-5555) \\ *Corresponding author \\ e-mail: momansor@kku.edu.sa; phone: +966-54-575-0250
}

(Received $30^{\text {th }}$ Dec 2018; accepted $14^{\text {th }}$ Feb 2019)

\begin{abstract}
Environmental protection requires adopting and implementing legal, economic, and societal procedures to limit the side effects of the massive real-estate and economic development in today's world. The purpose of this research was to investigate the implementation level of the eight main environmental laws affecting the construction industry in Saudi Arabia, and to identify the difficulties faced by practitioners to implement these laws. Using the descriptive analytical approach, this research described and analyzed the level of implementation of environmental laws using a Likert scale questionnaire distributed to 1000 organizations that work in 29 construction industry fields, in 13 Saudi Arabian regions. These questionnaires were filled out by engineers and professionals, authorized contractors, unauthorized contractors, individuals, and officials and owners. The one-way ANalysis Of VAriance (ANOVA) was applied to the data collected (at $<0.05$ level of significance), using SPSS Version 23.0 software. The overall environmental legitimacy implementation level in Saudi Arabia was found to be 2.95 out of 5.00 and a standard deviation of 1.13 indicating difficulties in defining the level for environmental legitimacy implementation in the construction industry. Results indicated that more attention was given to regulations related to the handling and disposal of radioactive materials, hazardous waste management, wastewater discharges, hazardous and dangerous substance compliance programs, environmental noise, general environmental requirements, air quality emissions, and external emergency planning with mean values of $3.23,3.12,3.10,3.06,3.05,2.95,2.80$, and 2.75 , respectively. Further investigation is required to evaluate internal auditing, accounting, and the availability of review teams regarding the environment in the industrial organizations in Saudi Arabia.
\end{abstract}

Keywords: environmental laws implementation, statistical analysis, construction industry

\section{Introduction}

Interest in environmental issues is widespread, with climate change and other environmental concerns receiving significant media attention and among the greatest threats facing the world today (White and Hunter, 2009). Today's, economic growth is based on the use of depleted energy resources leads to environmental pollution and stress. One the same time, it works to increase the development of individuals and society. Defining the equilibrium point between economic growth, societal development, and environmental pollution is one of the main points of concern to the world community in general and Saudi Arabia in particular. To coordinate the effort among the countries of the world, several international environmental agreements are 
signed concerning climate protection, Ozone layer, climate change, marine/water and environmental protection, availability of information and participation, waste management, prevention of environmental damage caused by chemicals, environmental impact assessment, protection of flora and fauna and biological diversity, and landscape besides the bilateral agreements. Moreover, the international effort seeks to include intergovernmental organization involvement as United Nations and World Trade Organization (Millimet and Roy, 2015; Eckersley, 2016; Barrett, 2005; Horn and Mavroidis, 2014; Kellenberg and Levinson, 2014).

Consequently, organizations are heavily implicated in these environmental issues. With greater awareness, the public is now demanding that organizations should take responsibility for voluntarily integrating social and environmental concerns into their operations and into their interactions with stakeholders. Organizations have responded to this call in a variety of ways, complying with regulatory requirements such as ISO 14001 certification and environmental responsibility (To and Lee, 2014). This synthesis of the literature delineates these three important concepts of corporate environmental performance and behavior, explains the causal links between the concepts, and depicts the concepts and causal links diagrammatically in a framework. Jordan et al. (2010) presented a model of environmental accountability and an outline of a process for achieving it and concluded that achieving and maintaining a sustainable environment requires more than accounting. They mention that actions, including legislation, regulation, mitigation, resource management, enforcement, education, and social responses to environmental challenges are the dynamic forces that produce results. Findings are environmental accounting can only tell us what those results are the ecosystem services paradigm, worthiness, and service to humanity. Environmental performance is the most important central concept in the framework. Improvements in environmental performance will eventually lead to the goal, namely sustainability. The general system of environmental protection and its executive regulation aims to protect the environment and prevent pollution, protect public health against the dangers of activities and actions harmful to the environment, conservation, development and rational use of natural resources, and make environmental planning an integral part of comprehensive planning for development in all industrial, agricultural, urban, and other fields (The General Authority of Meteorology and Environmental Protection, 2001).

In this context, an extensive body of literature has emerged recently on environmental legitimacy. The construction industry consumes a large portion of natural resources (Paudel et al., 2014), which has enormous side-effects, such as air and water pollution, deforestation, stratospheric ozone depletion, and increased threat of global warming (Hallett, 2002; Field, 2014). The government and public are setting an increasing number of legislative restrictions on businesses to implement more ecofriendly alternatives. The construction sector in Saudi Arabia includes a variety of activities such as construction, water piping, electrical connections, maintenance activities, and cleaning activities. Under these activities, there are multiple and interrelated sub-activities, which are classified into three basic groups: engineering design and consultancy; project execution, operation, and maintenance; and contracting activities. The fields of activity in this sector include building, roads, water and sanitation works, electrical work, mechanical work, industrial activities, marine works, dams, landscaping, afforestation, slaughterhouses, and building maintenance and operation (Contractor Classification Agency, Ministry of Municipal and Rural Affairs, 2018). The research work done in the field of environmental assessment of the 
construction industry has focused on measuring their environmental performance. The researchers noticed that, no research work has been done to assess the implementation of various environmental laws in any industrial sector. The main objective of this article is to present the results from analysis of the environmental legitimacy implementation in the Saudi Arabian construction industry.

\section{Literature review}

Legitimacy, as defined by Suchman (1995), is "a generalized perception or assumption that the actions of an entity are desirable, proper, or appropriate within some socially constructed system of norms, values, beliefs, and definitions". Expanding Suchman's (1995) definition of legitimacy into the environmental arena, Bansal and Clelland (2004) define environmental legitimacy as "the generalized perception or assumption that a firm's environmental performance is desirable, proper, or appropriate". Legitimacy is a complex concept, it is generally accepted that organizations have social responsibility towards society. On the other hand, legitimacy is temporally and culturally defined (Deegan, 2002), thus creating an immense challenge for organizations to secure legitimacy. Hutchins et al. (2019) utilized a stakeholder perspective to make the case that firms should focus on multiple constituents in order to be successful specifically with regard to building sustainability programs. They proposed a conceptual model and research propositions that can serve as a foundation for future research to empirically investigate the role of legitimacy in reducing skepticism of a comprehensive sustainability program. Building legitimacy, therefore, can serve as a foundation for operational and competitive success. The conditions of the social contract include granting of legal standing to organizations and offering support to an organization by supplying resources and labor.

A legitimacy gap can arise because of changing organizational performance, changing societal expectations, or a combination of both (Deegan, 2002). Furthermore, legitimacy can be both factual and perceptual. An example of factual legitimacy could be an environmental event (e.g., a catastrophic oil spill, or a fine for non-compliance), which is visible to stakeholders either by their own observation or through widespread media publicity. However, often external stakeholders cannot easily discern environmental performance (Hunter and Bansal, 2007), explaining the importance of perceptions. Legitimacy, as described above and adopted in the framework of this study, is concerned with a status or condition. Hence, it is essential to clarify, from the beginning, the difference between legitimacy (a status or condition) and legitimizing (an act or process aiming at legitimacy. Depending on whether the strategy is to gain, maintain, or repair legitimacy, an organization may engage stakeholders in the decisionmaking process, redefine its corporate mission statement, establish a separate department dealing with sustainability issues and/or obtain external certifications, contribute to charity, associate itself with other 'legitimate' institutions, and comply with legislation to appear legitimate in the eyes of its relevant publics (Bansal and Roth, 2000). While gaining legitimacy is proactive in nature, repairing legitimacy is generally a reaction to an unforeseen crisis (Suchman, 1995). Moreover, for any legitimizing strategy to be effective, communication between organizations and society is very important (Villiers and van Staden, 2006; Hasseldine et al., 2005; Toms, 2002).

Palazzo and Scherer (2006) proposed a fundamental shift to moral legitimacy, from an output and power-oriented approach to an input related and discursive concept of 
legitimacy. This shift creates a new basis of legitimacy and involves organizations in processes of active justification vis-a-vis society rather than simply responding to the demands of powerful groups. They consider this a step towards the politicization of the corporation and attempt to re-embed the debate on corporate legitimacy into its broader context of political theory, while reflecting the recent turn from a liberal to a deliberative concept of democracy (see also Aerts and Cormier, 2009; Brønn and Vidaver-Cohen, 2009). For such organizations, a symbolic response may only intensify the threat to legitimacy, and consequently, society would be more likely to demand more substantive change in organizational performance (see further Burchell and Cook, 2008). It is argued that a symbolic legitimacy strategy, due to its rhetoric and often manipulative nature, would not give the same positive impact and could possibly further detriment the organizational legitimacy. As a final note, it is important to emphasize that by setting environmental legitimacy as a desired goal, the framework does not simplify the overly complex reality by nullifying other possible motives. Organizations embrace social and environmental responsibility for numerous reasons (e.g., (Okereke, 2007; Solomon and Lewis, 2002; Williamson et al., 2006).

At the global level, researchers were interested in studying the relation between environmental laws and the application of these laws on the real world. They recommended concentrating on environmental protection through public awareness programs. For example, Fernandes Rei (2018) highlighted the southern approaches brought to international governance gets mixed with the addressing of the challenges facing the legal science in harmony with the others sciences to handle with the complex environmental issues of the 21 st century and concluded the southern influences suggest a more pragmatic, finalistic international law concerned about the results, the attainment of the targets suggested. Pavoni and Piselli (2016) introduced the implications for global environmental legislation of the maintenance of the continuous development goals, which occurred at the 2015 United Nations Sustainable Development Summit. Kelemen and Knievel (2015) pointed out the United States has lagged the European Union in its approval and implementation of significant multilateral environmental agreements. They argued varying levels of responsibility to substantive environmental management goals at the national level, rather than varying levels of commitment to international law, may best explain US and EU positions concerning international environmental policy.

Wang (2013) reviewed bureaucrats took positive efforts on environmental protection, making major investments in pollution control infrastructure in China. They seek to offer insight into several broader ongoing debates - about environmental regulation in developing countries, accountability and regime survival in authoritarian states, and legal development in China. Sand (2012) recommended a recent focus on techniques for support by the national community in the work and implementation of transnational environmental law. Van Kempen (2012) highlighted European environmental law has become progressively complex and needs the clarity to allow for adequate implementation and therefore effective environmental protection. Howarth (2011) focused the National Audit Office Report, Tackling Diffuse Water Pollution in England, addresses three issues: the Environment Agency's recognition of the causes of diffuse pollution; whether attention of diffuse pollution is being raised; and whether the Agency is well using its legal the latter because of diffuse pollution.

Yang and Percival (2009) addressed the global growth of public concern about environmental issues over the lost several decades, environmental legal norms have 
become increasingly internationalized called "global environmental law" for the implementation, practice, and development of environmental law worldwide. Fine and Owen (2005) explored the origins of legal requirements for both public participation and modeling and then considers how models fit within planning processes. They highlighted how planning depends upon models and how model use impedes the public role because of limitations inherent in modeling. Freeman and Farber (2005) proposed framed the enterprise of environmental regulation and resource management as an exercise in designing governance institutions capable of managing multiple and incompatible demands over the long term. This approach departs from the traditional legal framing of such environmental conflicts as shorter-term and zero-sum questions of jurisdiction, authority, entitlement, and prohibition.

The aim of this research was to evaluate the Saudi environmental laws implementation in the construction industry by category. In the next section the methodology will be explained.

\section{Methodology}

The methodology involved the data collection regarding Saudi Arabian environmental legislation, population and sample size of respondents, questionnaire, and statistical analysis along with questionnaire analysis using SPSS (Statistical Package for Social Sciences) Version 23.0. Table 1 highlights Saudi Arabian environmental legislation chronologically by promulgation date.

Table 1. Saudi Arabian environmental legislation chronologically by promulgation date

\begin{tabular}{c|c|c}
\hline No. & Teneral environmental & Date of issuance \\
\hline \multicolumn{2}{c}{ Environmental Law } \\
Arbitration Law & 2001 \\
2 & Air quality/emissions & 2012 \\
\hline 3 & Ambient Air Standard 2012 & 2012 \\
4 & Standard on Emissions from Mobile Sources 2012 & 2012 \\
\hline \multicolumn{2}{c}{ Water/wastewater } \\
\hline 5 & Wastewater Discharge Standard of 2012 & 2012 \\
\hline & Hazardous/non-hazardous waste & 2012 \\
\hline 7 & Basel Convention on the Control of Trans boundary Movements of Hazardous Wastes \\
\hline 8 & and their Disposal & 1989 \\
9 & Hegulations and Procedures for Hazardous Waste Control (Document No. 01-2002) & 2092 \\
10 & Environmental Standards on Material Recovery and Recycling of Waste 2012 & 2012 \\
\hline \multicolumn{2}{c}{ Hazardous/dangerous substances } \\
\hline 11 & Technical Guideline of 2012 on the Prevention of Major Accidents & 2012 \\
\hline
\end{tabular}

\section{Saudi Arabian environmental legislation}

The first comprehensive Saudi Arabian national environmental legislation was enacted on September 24, 2001 in the form of the General Environmental Regulation, Council of Ministers Resolution No. 193. It entered into force on October 31, 2002, and 
its Implementing Rules were published on September 30, 2003. Under the Regulation, the Presidency of Meteorology and Environment (PME), an agency of the Ministry of Defense, is charged with the general supervision of environmental affairs in Saudi Arabia. The legislation sets out wide-ranging prohibitions of pollution and contamination of air, land, and water, with reference to all parties involved in services, industry, or other economic activities. Owners of 'projects' that might influence the environment, are required to comply with existing and future environmental specifications, standards, measurements, and guidelines as promulgated by the PME and set out in the appendices of the Implementing Rules. Moreover, prior to the setting up of a project, an environmental evaluation study must be completed and approved by the PME.

The detail of the legislation is contained in the appendices of the Implementing Rules, as Environmental Protection Standards, Procedures for the Assessment of Environmental Effects of Industrial and Development Projects, Manual of Environmental Qualification Procedures, Rules and Procedures for the Control of Hazardous Waste, National Contingency Plan for Combatting Pollution by Oil and other Harmful Substances of the Marine Environment in Emergency Cases, and Violations and Fines. Apart from the above national environmental legislation, the following specific regulations are also applicable in certain areas of Saudi Arabia:

- The Royal Commission for the industrial cities of Jubail and Yanbu has issued detailed local environmental regulations applicable to facilities located within the Royal Commission areas and contractors operating therein, of which the Jubail Industrial City Royal Commission Environmental Regulations of September 1999 are the most recent.

- Pollution and contamination incidents within ports under the administration of the Saudi Arabian Seaports Authority are governed by the Rules and Regulations for Seaports of the Co-operation Council for the Arab States of the Gulf of 1985, as revised in 2006.

- Saudi Aramco, which administers the oil loading terminals at Ras Tanura, Ju'aymah, and several smaller terminals independently of the of the Seaports Authority, has its own set of rules entitled "Saudi Aramco, Oil Ports \& Terminals, Rules, Regulations and General Information."

- Saudi Arabia has ratified the International Convention for the Prevention of Pollution of the Sea by Oil of 1954 (OILPOL 1954, 1958) and its Amendments of 1962, 1969, and 1971, and the International Convention on Civil Liability for Oil Pollution Damage of 1969 (CLC, 1969) and its Protocols of 1976 and 1992.

Table 1 lists the Saudi Arabian environmental legislation chronologically by promulgation date that adopted in this research. Table 2 lists the questions for the designed questionnaire.

\section{Population and sample size}

A survey of construction industry fields was conducted in which the respondent categories included engineers and professionals, authorized contractors, unauthorized contractors, individuals, and officials and owners, along various Saudi Arabian regions. Of the total construction industries $(18,573)$ only 1,000 were incorporated into the 
survey analysis. From the respondent category of engineers and professionals, a greater number of respondents were from the categories individual, maintenance and operation for electrical works, and city cleaning and waste disposal from a total of 202 construction industries. Authorized contractors showed more response from building maintenance, from the total of 29 industries. From unauthorized contractors, a greater number of responses were received from buildings, and from maintenance and operation of electrical works, from a total of 29 industries. The category 'individual' got more responses from city cleaning and waste disposal, from among 196. Officials and owners had more responses from catering for medical centers, among 189.

When Saudi regions were compared with construction industries, the eastern region got more responses for water and sanitation, and maintenance roads among 453 districts, regarding 114 industrial fields. The Al Baha region had almost no responses among nine fields, as did the Al-Jouf region among 13 fields and the northern border region among six fields. The Riyadh region responded better in all fields when compared to all other regions as it showed more response towards city cleaning and waste disposal among 443 fields. The remaining regions, like Qassim (62 fields), Madinah (35 fields), Tabuk (12 fields), Jazan (10 fields), Hail (17 fields), Asir (62 fields), and Najran (44 fields) showed less response. The Makkah region responded for catering by individuals from among 173 fields. The details for the sampling plan are shown in Table 3.

\section{Questionnaire}

After extensive review of the literature and studies related to environmental assessment, it was decided that the questionnaire was the most suitable method for data collection. For this purpose, a questionnaire was designed to meet the objectives of the research and the requirements for answering its questions. These questions consisted of eight sections as general requirements, air quality/emissions, waste water discharges, hazardous waste management, radioactive materials handling and disposal, hazardous/dangerous substance compliance programs, environmental noise, and external emergency planning. The sections include 7, 6, 6, 7, 2, 6, 3, and 12 questions, respectively, as shown in Table 2 .

Table 2. Environmental questionnaire questions

\begin{tabular}{|c|c|c|c|}
\hline \multicolumn{2}{|r|}{ Environmental requirements } & \multicolumn{2}{|r|}{ Environmental requirements } \\
\hline & F1. General requirments & F4.7 & $\begin{array}{l}\text { Hazardous wastes spill prevention systems in } \\
\text { accordance with any applicable regulations }\end{array}$ \\
\hline F1.1 & Up-to-date operating license & & F5. Radioactive materials handling and disposal \\
\hline F1.2 & $\begin{array}{l}\text { Environmental violations relating to } \\
\text { environmental matters approved or signed? }\end{array}$ & F5.1 & $\begin{array}{l}\text { Handle the final disposal of radioactive materials, with } \\
\text { the procedures the Rules }\end{array}$ \\
\hline F1.3 & $\begin{array}{l}\text { Environmental impact assessment done } \\
\text { during the project feasibility stage }\end{array}$ & F5 5.2 & $\begin{array}{l}\text { Storage, treatment, recycling, and transportation of } \\
\text { radioactive wastes, in accordance to regulations }\end{array}$ \\
\hline F1.4 & $\begin{array}{l}\text { Making modifications to an existing project, } \\
\text { using technologies with lowest level of } \\
\text { pollution to the environment }\end{array}$ & \multicolumn{2}{|r|}{ F6. Hazardous/dangerous substance compliance programs } \\
\hline $\mathrm{F} 1.5$ & $\begin{array}{l}\text { Use of natural resources and apply recycling } \\
\text { technologies and reuse of resources }\end{array}$ & F6.1 & $\begin{array}{l}\text { Records maintained of dangerous chemicals used and } \\
\text { stored }\end{array}$ \\
\hline F1.6 & $\begin{array}{l}\text { Planning for projects and programs, with } \\
\text { developing environmental aspects }\end{array}$ & F6.2 & $\begin{array}{l}\text { Handling of final disposal of poisonous, hazardous } \\
\text { materials, with the procedures }\end{array}$ \\
\hline F1.7 & $\begin{array}{l}\text { Regulations and standards when designing or } \\
\text { operating any project or activity }\end{array}$ & F6.3 & $\begin{array}{l}\text { Treatment, recycling, and transportation of hazardous } \\
\text { waste as per regulation }\end{array}$ \\
\hline
\end{tabular}




\begin{tabular}{|c|c|c|c|}
\hline \multicolumn{2}{|r|}{ F2. Air quality/emissions } & \multirow{2}{*}{$\begin{array}{l}\text { F6.4 } \\
\text { F6.5 }\end{array}$} & \multirow{2}{*}{$\begin{array}{l}\text { License and approval to perform disposal of hazardous } \\
\text { waste as per regulation } \\
\text { Responsibility for any incidents of environmental } \\
\text { pollution and reporting of any incident }\end{array}$} \\
\hline F2.1 & $\begin{array}{l}\text { Stationary sources of air emissions and } \\
\text { recording of sources }\end{array}$ & & \\
\hline F2.2 & Air emission limit details & F6.6 & $\begin{array}{l}\text { Training programs for the handling, transportation, } \\
\text { storage, recycling, disposal of toxic, hazardous, waste }\end{array}$ \\
\hline F2.3 & $\begin{array}{l}\text { Emission frequency and methodology for } \\
\text { monitoring, and evaluation }\end{array}$ & \multicolumn{2}{|r|}{ F7. Environmental noise } \\
\hline F2.4 & $\begin{array}{l}\text { Emission within allowable limits permitted in } \\
\text { the environmental standards }\end{array}$ & F7.1 & $\begin{array}{l}\text { Prevention of noise pollution when operating } \\
\text { machinery or other equipment or using horns or } \\
\text { loudspeakers }\end{array}$ \\
\hline F2.5 & $\begin{array}{l}\text { No leaking or emission of air pollutants into } \\
\text { the work place beyond the allowable limits }\end{array}$ & F7.2 & $\begin{array}{l}\text { Check noise levels do not exceed allowable } \\
\text { environmental standard limits }\end{array}$ \\
\hline F2.6 & Adequate ventilation system & F7.3 & $\begin{array}{l}\text { Upgrade technologies and equipment used in existing } \\
\text { activities to attain allowable noise levels }\end{array}$ \\
\hline \multicolumn{2}{|r|}{ F3. Waste water discharges } & \multicolumn{2}{|r|}{ F8. External emergency planning } \\
\hline F3.1 & $\begin{array}{l}\text { Prevention of contamination of surface and } \\
\text { ground waters }\end{array}$ & F8.1 & $\begin{array}{l}\text { Emergency plans to prevent or alleviate the hazards of } \\
\text { such impacts }\end{array}$ \\
\hline F3.2 & Prohibition of discharge of harmful pollutants & F8.2 & $\begin{array}{l}\text { Importance to environmental aspects while planning } \\
\text { for projects and programs }\end{array}$ \\
\hline F3.3 & $\begin{array}{l}\text { Wastewater discharge to treatment plant or } \\
\text { Municipal zone }\end{array}$ & F8.3 & $\begin{array}{l}\text { Facility to cope Environmental disaster management } \\
\text { plans }\end{array}$ \\
\hline F3.4 & $\begin{array}{l}\text { Discharge of waste water to natural } \\
\text { environment with permission }\end{array}$ & F8.4 & $\begin{array}{l}\text { Environmental protection from pollution resulting } \\
\text { from conducted projects }\end{array}$ \\
\hline F3.5 & $\begin{array}{l}\text { Discharge of wastewater; are any of the } \\
\text { compounds, exceeded? }\end{array}$ & F8.5 & $\begin{array}{l}\text { Training given with technical emergency } \\
\text { environmental protection plans }\end{array}$ \\
\hline F3.6 & Limitation level in Mixing Zone, exceeded? & F8.6 & $\begin{array}{l}\text { Emergency plans in case of a pollution emergency } \\
\text { incident }\end{array}$ \\
\hline \multicolumn{2}{|r|}{ azardous waste management } & F8.7 & $\begin{array}{l}\text { Coordination to safe employees from environmental } \\
\text { damage resulting from emergency pollution incidents }\end{array}$ \\
\hline F4.1 & $\begin{array}{l}\text { License or permit for the handling of } \\
\text { hazardous wastes }\end{array}$ & F88.8 & Emergency plans to handle hazards situation \\
\hline F4.2 & $\begin{array}{l}\text { Hazardous waste disposal standards (1413- } \\
03) ?\end{array}$ & F8.9 & $\begin{array}{l}\text { Emergency plans with qualified work force and } \\
\text { equipment }\end{array}$ \\
\hline F4.3 & $\begin{array}{l}\text { Permit for transport and/ disposal of } \\
\text { hazardous wastes? }\end{array}$ & F8.10 & $\begin{array}{l}\text { Emergency plans for projects conducted and prevent } \\
\text { or alleviate the risks of potential adverse } \\
\text { environmental impacts }\end{array}$ \\
\hline F4.4 & $\begin{array}{l}\text { Record of hazardous wastes and disposal in } \\
\text { accordance to regulations? }\end{array}$ & F8.11 & $\begin{array}{l}\text { Periodically review of emergency plans that protect } \\
\text { the environment from pollution or prevent adverse } \\
\text { impacts on the environment }\end{array}$ \\
\hline F4.5 & $\begin{array}{l}\text { Check hazardous wastes are not mixed with } \\
\text { other types of waste }\end{array}$ & F8.12 & $\begin{array}{l}\text { Conduct periodical trial drills regarding the } \\
\text { implementation of emergency plans }\end{array}$ \\
\hline F4.6 & $\begin{array}{l}\text { Hazardous wastes labeled during storage in } \\
\text { accordance with regulations }\end{array}$ & & \\
\hline
\end{tabular}

***Correlation is significant at the 0.01 level (2-tailed)

A Likert scale (Table 4) was used to measure the responses of participants to the questionnaire elements. The questions were discussed with 30 reviewers in concerned governmental agencies, and then modified according to reviewer feedback to evaluate their validity. Cronbach's alpha was used to measure the questionnaire's internal consistency, which was found to be 0.71 by SPSS, indicating a high level of consistency. Table 5 shows the Pearson correlation coefficient $(\rho)$ between each questionnaire item and the corresponding dimension. All coefficients were positive 
except F1.2 was negative, as a higher item's score represented a good correlation for the dimension. It shows the significance of items to the corresponding dimension.

Table 3. Population and sample size details

\begin{tabular}{|c|c|c|c|c|c|c|c|c|c|c|c|c|c|c|c|c|c|c|c|}
\hline \multirow[b]{2}{*}{$\begin{array}{l}\text { Construction industry field (Contractor } \\
\text { Classification Agency, Ministry of } \\
\text { Municipal and Rural Affairs, 2018) }\end{array}$} & \multicolumn{5}{|c|}{ Respondents category } & \multicolumn{13}{|c|}{ Saudi Arabia's region } & \multirow[b]{2}{*}{ 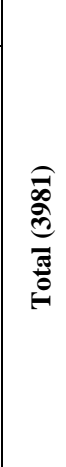 } \\
\hline & 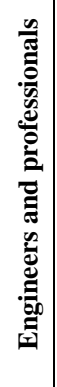 & 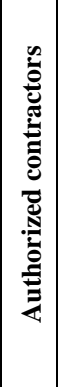 & 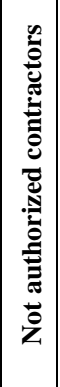 & 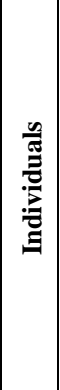 & 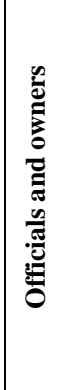 & 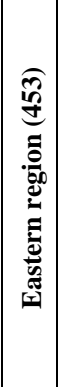 & 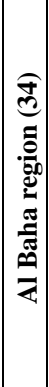 & 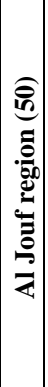 & 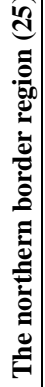 & 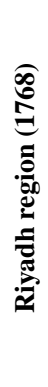 & 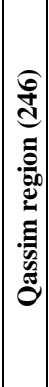 & 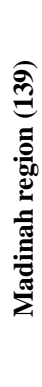 & 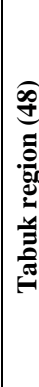 & 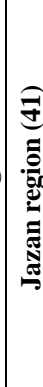 & 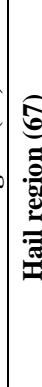 & 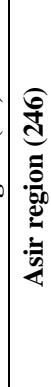 & 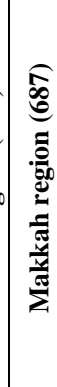 & 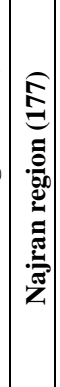 & \\
\hline CI01: Water \& sanitation works (2273 & 7 & 7 & 9 & 8 & 8 & 10 & 0 & 1 & 0 & 12 & 2 & 1 & 1 & 0 & 1 & 3 & 7 & 1 & 39 \\
\hline CI02: Electronic works (1025) & 5 & 8 & 6 & 6 & 3 & 8 & 0 & 0 & 0 & 8 & 3 & 1 & 1 & 0 & 0 & 2 & 4 & 1 & 28 \\
\hline CI03: Marine works (102) & 8 & 10 & 8 & 4 & 6 & 2 & 0 & 0 & 0 & 12 & 2 & 2 & 0 & 1 & 1 & 3 & 11 & 2 & 36 \\
\hline CI04: Industrial works (175) & 4 & 7 & 11 & 10 & 9 & 2 & 0 & 0 & 0 & 20 & 3 & 1 & 0 & 0 & 0 & 4 & 10 & 1 & 41 \\
\hline CI05: Electrical works (2397) & 10 & 6 & 10 & 4 & 3 & 3 & 0 & 0 & 0 & 9 & 2 & 2 & 1 & 1 & 1 & 3 & 10 & 1 & 33 \\
\hline CI06: Mechanical works (1641) & 5 & 4 & 11 & 9 & 5 & 3 & 0 & 1 & 0 & 9 & 2 & 1 & 0 & 0 & 1 & 3 & 12 & 2 & 34 \\
\hline CI07: Dams (671) & 3 & 9 & 5 & 5 & 7 & 2 & 0 & 0 & 0 & 18 & 2 & 1 & 0 & 0 & 0 & 2 & 3 & 1 & 29 \\
\hline CI08: Roads (1949) & 10 & 11 & 6 & 6 & 6 & 3 & 0 & 0 & 0 & 12 & 1 & 2 & 1 & 1 & 1 & 3 & 13 & 2 & 39 \\
\hline CI09: Buildings (3201) & 8 & 5 & 14 & 9 & 5 & 3 & 0 & 1 & 0 & 15 & 3 & 1 & 0 & 0 & 0 & 4 & 13 & 1 & 41 \\
\hline CI10: Slaughterhouses (60) & 8 & 7 & 5 & 3 & 8 & 3 & 0 & 0 & 0 & 15 & 2 & 1 & 0 & 0 & 1 & 1 & 6 & 2 & 31 \\
\hline CI11: Catering for individuals (152) & 13 & 12 & 10 & 8 & 12 & 5 & 0 & 1 & 0 & 16 & 2 & 1 & 1 & 1 & 1 & 3 & 23 & 1 & 55 \\
\hline CI12: Maintenance health centers (85) & 16 & 4 & 5 & 3 & 7 & 3 & 0 & 0 & 0 & 23 & 2 & 2 & 0 & 0 & 0 & 2 & 2 & 1 & 35 \\
\hline CI13: Landscaping (1017) & 5 & 5 & 8 & 6 & 9 & 2 & 1 & 0 & 0 & 20 & 1 & 1 & 0 & 1 & 1 & 1 & 3 & 2 & 33 \\
\hline CI14: Communication technology (576) & 5 & 10 & 11 & 13 & 10 & 6 & 1 & 1 & 1 & 30 & 2 & 1 & 0 & 0 & 0 & 2 & 3 & 2 & 49 \\
\hline CI15: Well drilling (49) & 5 & 3 & 3 & 4 & 9 & 8 & 1 & 0 & 0 & 0 & 2 & 1 & 0 & 0 & 0 & 1 & 4 & 1 & 6 \\
\hline CI16: Maintenance of & 6 & 7 & 11 & 10 & 5 & 7 & 1 & 1 & 0 & 12 & 2 & 1 & 0 & 0 & 1 & 2 & 10 & 2 & 9 \\
\hline CI17: Maintenance and operation dams (32) & 2 & 3 & 3 & 4 & 0 & 1 & 1 & 1 & 0 & 0 & 2 & 2 & 1 & 0 & 0 & 2 & 0 & 2 & 12 \\
\hline CI18: Maintenance roads (330) & 9 & 9 & 1 & 12 & 12 & 10 & 1 & 1 & 0 & 15 & 2 & 1 & 0 & 1 & 1 & 1 & 9 & 1 & 43 \\
\hline CI19: Maintenance buildings (513) & 6 & 15 & 9 & 8 & 8 & 4 & 1 & 0 & 0 & 24 & 2 & 1 & 1 & 0 & 0 & 2 & 9 & 2 & 46 \\
\hline CI20: Catering for medical centers (429) & 6 & 13 & 6 & 6 & 14 & 6 & 1 & 1 & 0 & 23 & 2 & 1 & 0 & 0 & 1 & 2 & 6 & 2 & 45 \\
\hline $\begin{array}{l}\text { CI21: Maintenance and operation of water \& } \\
\text { sanitation works (179) }\end{array}$ & 4 & 4 & 1 & 6 & 3 & 2 & 1 & 1 & 1 & 4 & 2 & 1 & 0 & 1 & 0 & 2 & 2 & 1 & 8 \\
\hline $\begin{array}{l}\text { CI22: Maintenance and operation of } \\
\text { electronic works (118) }\end{array}$ & 6 & 6 & 4 & 8 & 5 & 2 & 0 & 0 & 0 & 12 & 3 & 2 & 0 & 0 & 1 & 1 & 6 & 2 & 29 \\
\hline $\begin{array}{c}\text { CI23: Maintenance and operation of marine } \\
\text { works (17) }\end{array}$ & 4 & 2 & 2 & 3 & 6 & 2 & 0 & 0 & 0 & 4 & 2 & 1 & 0 & 1 & 1 & 2 & 2 & 2 & 17 \\
\hline $\begin{array}{l}\text { CI24: Maintenance and operation of } \\
\text { industrial works (32) }\end{array}$ & 4 & 5 & 5 & 3 & 1 & 2 & 0 & 1 & 1 & 4 & 2 & 1 & 1 & 1 & 1 & 2 & 1 & 1 & 18 \\
\hline $\begin{array}{l}\text { CI25: Maintenance and operation of } \\
\text { electrical works (272) }\end{array}$ & 13 & 9 & 14 & 9 & 6 & 5 & 0 & 0 & 1 & 35 & 3 & 1 & 1 & 0 & 0 & 2 & 1 & 2 & 51 \\
\hline $\begin{array}{l}\text { C126: Maintenance and operation of } \\
\text { mechanical works (178) }\end{array}$ & 4 & 3 & 3 & 2 & 5 & 2 & 0 & 0 & 1 & 5 & 2 & 1 & 1 & 0 & 1 & 2 & 1 & 1 & 17 \\
\hline $\begin{array}{l}\text { CI27: Maintenance and operation of } \\
\text { slaughterhouses (68) }\end{array}$ & 6 & 4 & 6 & 9 & 4 & 2 & 0 & 1 & 0 & 16 & 2 & 1 & 1 & 1 & 1 & 2 & 1 & 1 & 29 \\
\hline $\begin{array}{l}\text { CI28: Maintenance and operation of } \\
\text { communication technology (33) }\end{array}$ & 7 & 6 & 7 & 4 & 7 & 2 & 0 & 0 & 1 & 18 & 3 & 1 & 1 & 0 & 1 & 1 & 1 & 2 & 31 \\
\hline CI29: City cleaning \& wastes disposal (677) & 13 & 15 & 8 & 14 & 6 & 4 & 0 & 1 & 0 & 44 & 2 & 1 & 0 & 0 & v & 2 & 0 & 2 & 56 \\
\hline Total (18573) & 202 & 209 & 204 & 196 & 189 & 114 & 9 & 13 & 6 & 443 & 62 & 35 & 12 & 0 & 17 & 762 & 173 & 44 & 1000 \\
\hline
\end{tabular}


Table 4. Five-point Likert scale

\begin{tabular}{c|c|c|c|c|c}
\hline Response & Strongly agree & Agree & Neither & Disagree & Strongly disagree \\
\hline Degree & 5 & 4 & 3 & 2 & 1 \\
The weighted average & $4.20-5.00$ & $3.40-4.19$ & $2.60-3.39$ & $1.80-2.59$ & $1.00-1.79$ \\
\hline
\end{tabular}

Table 5. Pearson correlation coefficient ( $\rho$ ) between each sub-factor with main factors

\begin{tabular}{c|c|c|c|c|c|c|c|c|c|c|c|c|c}
\hline Code & $\rho$ & Code & $\rho$ & Code & $\rho$ & Code & $\boldsymbol{\rho}$ & Code & $\boldsymbol{\rho}$ & Code & $\boldsymbol{\rho}$ & Code & $\boldsymbol{\rho}$ \\
\hline F1.1 & $0.961^{* *}$ & F2.1 & $0.790^{* *}$ & F3.2 & $0.629^{* *}$ & F4.3 & $0.570^{* *}$ & F6.1 & $0.592^{* *}$ & F7.2 & $0.647^{* *}$ & F8.6 & $0.549^{* *}$ \\
F1.2 & $-0.928^{* *}$ & F2 2 & $0.902^{* *}$ & F3.3 & $0.595^{* *}$ & F4.4 & $0.533^{* *}$ & F6.2 & $0.645^{* *}$ & F7.3 & $0.598^{* *}$ & F8.7 & $0.614^{* *}$ \\
F1.3 & $0.710^{* *}$ & F2.3 & $0.974^{* *}$ & F3.4 & $0.652^{* *}$ & F4.5 & $0.568^{* *}$ & F6.3 & $0.391^{* *}$ & F8.1 & $0.328^{* *}$ & F8.8 & $0.638^{* *}$ \\
F1.4 & $0.865^{* *}$ & F2.4 & $0.897^{* *}$ & F3.5 & $0.664^{* *}$ & F4.6 & $0.560^{* *}$ & F6.4 & $0.446^{* *}$ & F8.2 & $0.185^{* *}$ & F8.9 & $0.583^{* *}$ \\
F1.5 & $0.949^{* *}$ & F2.5 & $0.934^{* *}$ & F3.6 & $0.648^{* *}$ & F4.7 & $0.528^{* *}$ & F6.5 & $0.330^{* *}$ & F8.3 & $0.610^{* *}$ & F8.10 & $0.615^{* *}$ \\
F1.6 & $0.924^{* *}$ & F2.6 & $0.889^{* *}$ & F4.1 & $0.661^{* *}$ & F5.1 & $0.687^{* *}$ & F6.6 & $0.463^{* *}$ & F8.4 & $0.607^{* *}$ & F8.11 & $0.587^{* *}$ \\
F1.7 & $0.882^{* *}$ & F3.1 & $0.788^{* *}$ & F4.2 & $0.240^{* *}$ & F5.2 & $0.690^{* *}$ & F7.1 & $0.596^{* *}$ & F8.5 & $0.443^{* *}$ & F8.12 & $0.577^{* *}$ \\
\hline
\end{tabular}

$* *$ Correlation is significant at the 0.01 level (2-tailed)

\section{Statistical analysis}

For this work, the Statistical Package for the Social Sciences (IBM SPSS Statistics, 2015) was used for data description and analysis. The following techniques were used:

- Descriptive statistics measures to describe the collected data in terms of frequencies, mean, and standard deviation.

- Cronbach's alpha was used to measure the questionnaire's internal consistency.

- Pearson correlation coefficient $(\rho)$ was used to measure the correlation of each subfactor with the related factor.

- One-way ANOVA was used to evaluate whether the mean of data from one group was different from the others.

- Levene's test was used to measure homogeneities between sample groups.

The statistical analysis and test results at the 0.05 level of significance are described in the next section. Also, the performance of the law implementation score in addition to the performance for each construction industry category is estimated based on the collected data.

\section{Results and discussion}

Table 6 reflects the overall average and average environmental performance of each factor for of the 13 regions. The table highlights that the overall average Likert scale value for Asir, Riyadh, Madinah, Makkah, Eastern, Najran, Al Baha, and Qassim regions are 3.03, 3.03, 3.04, 3.09, 3.01, 3.10, 3.02, and 3.08 respectively. This indicates that the environmental laws implementation is seen more in the southern part of the KSA. The remaining regions perform less than 2.99. Also, the table shows that industry categories get a mean Likert scale value of 3.23, 3.12, 3.10, 3.06, 3.05, 2.95, 2.80, and 2.75 for radioactive materials handling and disposal (F5), hazardous waste management (F4), wastewater discharges (F3), hazardous dangerous substance compliance programs 
(F6), environmental noise (F7), general environmental requirements (F1), air quality emissions (F2), and external emergency planning (F8). These factors have high exposure of harmful effects on the environment which should be controlled.

Table 7 shows the overall average and average environmental performance of each factor of the 29 construction industry categories KSA. It highlights the average Likert scale score for slaughterhouses, catering for individuals, landscaping, maintenance buildings, maintenance and operation of slaughterhouses, maintenance and operation of communication technology, maintenance and operation of electrical works, city cleaning \& wastes disposal, roads, marine works, maintenance and operation of electronic works, maintenance and operation of mechanical works, electrical works, catering for medical centers, buildings, maintenance health centers, industrial works, dams, maintenance roads, and maintenance and operation of marine works are 3.21, $3.20,3.19,3.14,3.13,3.11,3.09,3.09,3.08,3.08,3.07,3.07,3.06,3.06,3.04,3.02$, $3.01,3.01,3.01$, and 3.00 respectively highlighted in the table by a green color. Twenty construction industry categories achieve a score greater than 3.00. This indicating that these industries follows to some extend the Saudi environmental laws.

These industries are imposed by strict rules of Saudi government and continuous monitoring done to protect the environments and heavy penalties imposed if disposed in a wrong manner. The environmental monitoring system and procedures in Saudi Arabia is done with perfection to save the environment and maintain the society.

The remaining industries as electronic works, mechanical works, water \& sanitation works, maintenance of landscaping, maintenance and operation of industrial works, communication technology, maintenance and operation of water $\&$ sanitation works, well drilling, and maintenance and operation dams achieve a total score between 2.802.99 with average Likert scores of 2.95, 2.94, 2.93, 2.90, 2.89, 2.86, 2.86, 2.81, and 2.80 respectively, as these construction industries are far away from city dominated areas and does not affect the environment. Also, the performance of the factors is similar to data in Table 6.

Table 6. The overall average and average environmental performance of each factor for of the 13 regions

\begin{tabular}{|c|c|c|c|c|c|c|c|c|c|c|}
\hline \multirow{2}{*}{ Region } & \multicolumn{8}{|c|}{ Environmental law category (mean Likert scale value) } & \multirow{2}{*}{$\begin{array}{l}\text { Overall } \\
\text { average }\end{array}$} & \multirow{2}{*}{ Rank } \\
\hline & F1 & F2 & F3 & F4 & F5 & F6 & F7 & F8 & & \\
\hline Jazan region & 2.66 & 2.43 & 2.85 & 2.89 & 3.05 & 3.05 & 3.07 & 2.48 & 2.83 & 12 \\
\hline The Northern Border region & 2.69 & 2.19 & 2.89 & 3.19 & 3.50 & 2.86 & 3.11 & 2.32 & 2.88 & 11 \\
\hline Al Jouf Region & 2.78 & 2.33 & 2.92 & 3.16 & 2.88 & 2.77 & 3.23 & 2.46 & 2.78 & 13 \\
\hline Hail region & 2.82 & 2.53 & 2.88 & 3.26 & 3.32 & 3.10 & 3.27 & 2.55 & 2.98 & 9 \\
\hline Tabuk region & 2.85 & 2.69 & 3.14 & 2.89 & 2.83 & 2.90 & 3.28 & 2.67 & 2.90 & 10 \\
\hline Asir region & 2.93 & 2.93 & 3.11 & 3.09 & 3.23 & 2.98 & 3.07 & 2.78 & 3.03 & 6 \\
\hline Riyadh region & 2.95 & 2.82 & 3.09 & 3.08 & 3.27 & 3.08 & 3.00 & 2.76 & 3.03 & 5 \\
\hline Madinah region & 2.96 & 2.83 & 3.13 & 3.26 & 3.21 & 3.14 & 3.15 & 2.68 & 3.04 & 4 \\
\hline Makkah region & 2.99 & 2.95 & 3.15 & 3.19 & 3.29 & 3.10 & 3.07 & 2.86 & 3.09 & 2 \\
\hline Eastern Region & 3.00 & 2.86 & 3.14 & 3.09 & 3.10 & 3.09 & 3.03 & 2.80 & 3.01 & 8 \\
\hline Najran region & 3.02 & 2.98 & 3.13 & 3.30 & 3.34 & 3.06 & 3.06 & 2.89 & 3.10 & 1 \\
\hline Al Baha region & 3.06 & 2.70 & 2.83 & 3.17 & 3.50 & 3.06 & 2.96 & 2.56 & 3.02 & 7 \\
\hline Qassim region & 3.09 & 3.03 & 3.19 & 3.18 & 3.10 & 3.10 & 3.18 & 2.89 & 3.08 & 3 \\
\hline Average & 2.95 & 2.80 & 3.10 & 3.12 & 3.23 & 3.06 & 3.05 & 2.75 & 2.95 & \\
\hline Rank & 6 & 7 & 3 & 2 & 1 & 4 & 5 & 8 & & \\
\hline
\end{tabular}


Table 7. The overall average and average environmental performance of each factor for the 29 industry

\begin{tabular}{|c|c|c|c|c|c|c|c|c|c|c|}
\hline \multirow{2}{*}{ Construction industry category } & \multicolumn{8}{|c|}{ Environmental law category (mean Likert scale value) } & \multirow{2}{*}{$\begin{array}{l}\text { Overall } \\
\text { average }\end{array}$} & \multirow{2}{*}{ Rank } \\
\hline & F1 & F2 & F3 & F4 & F5 & F6 & F7 & F8 & & \\
\hline Slaughterhouses & 3.09 & 2.98 & 3.28 & 3.50 & 3.45 & 3.26 & 3.18 & 2.95 & 3.21 & 1 \\
\hline Catering for individuals & 3.01 & 3.15 & 3.25 & 3.22 & 3.32 & 3.00 & 3.39 & 3.14 & 3.20 & 2 \\
\hline Landscaping & 3.12 & 3.17 & 3.16 & 3.17 & 3.26 & 3.41 & 3.18 & 2.98 & 3.19 & 3 \\
\hline Maintenance buildings & 3.01 & 2.97 & 3.17 & 3.19 & 3.42 & 3.26 & 3.02 & 2.80 & 3.14 & 4 \\
\hline Maintenance and operation of slaughterhouses & 3.14 & 2.78 & 3.39 & 3.25 & 3.28 & 2.99 & 3.44 & 2.78 & 3.13 & 5 \\
\hline Maintenance and operation of comm. Tech. & 3.00 & 2.64 & 3.18 & 3.07 & 3.55 & 3.08 & 3.27 & 2.65 & 3.11 & 6 \\
\hline Maintenance and operation of electrical works & 3.00 & 2.84 & 3.19 & 3.22 & 3.32 & 3.09 & 3.24 & 2.76 & 3.09 & 8 \\
\hline City cleaning \& wastes disposal & 3.09 & 2.91 & 3.26 & 3.17 & 3.20 & 3.19 & 3.07 & 2.83 & 3.09 & 7 \\
\hline Roads & 2.98 & 2.92 & 3.15 & 3.11 & 3.27 & 3.04 & 3.02 & 3.00 & 3.08 & 10 \\
\hline Marine works & 3.10 & 3.26 & 3.23 & 2.94 & 3.04 & 3.13 & 2.92 & 2.90 & 3.08 & 9 \\
\hline Maintenance and operation of electronic works & 2.93 & 2.73 & 3.28 & 3.22 & 3.43 & 3.06 & 2.93 & 2.75 & 3.07 & 12 \\
\hline Maintenance and operation of mechanical works & 3.00 & 2.72 & 3.21 & 3.07 & 3.32 & 2.94 & 3.29 & 2.72 & 3.07 & 11 \\
\hline Electrical works & 2.90 & 3.05 & 3.10 & 3.03 & 3.39 & 3.14 & 2.70 & 2.79 & 3.06 & 14 \\
\hline Catering for medical centers & 2.94 & 2.62 & 3.13 & 3.13 & 3.41 & 2.99 & 3.39 & 2.56 & 3.06 & 13 \\
\hline Buildings & 2.92 & 2.78 & 2.96 & 3.34 & 3.38 & 3.05 & 3.06 & 2.82 & 3.04 & 15 \\
\hline Maintenance health centers & 2.80 & 2.79 & 2.87 & 2.94 & 3.33 & 3.03 & 3.28 & 2.77 & 3.02 & 16 \\
\hline Industrial works & 2.93 & 3.04 & 2.98 & 2.98 & 3.18 & 3.20 & 2.89 & 2.70 & 3.01 & 19 \\
\hline Dams & 2.92 & 2.87 & 3.20 & 3.25 & 3.41 & 2.98 & 2.63 & 2.66 & 3.01 & 18 \\
\hline Maintenance roads & 2.98 & 2.88 & 3.02 & 3.09 & 3.12 & 3.16 & 2.97 & 2.82 & 3.01 & 17 \\
\hline Maintenance and operation of marine works & 2.88 & 2.61 & 3.19 & 3.20 & 3.26 & 3.08 & 3.06 & 2.67 & 3.00 & 20 \\
\hline Electronic works & 2.97 & 3.10 & 2.98 & 3.05 & 2.88 & 2.90 & 3.10 & 2.82 & 2.95 & 21 \\
\hline Mechanical works & 2.82 & 2.71 & 2.87 & 3.14 & 3.37 & 3.03 & 2.71 & 2.64 & 2.94 & 22 \\
\hline Water \& sanitation works & 3.08 & 3.00 & 3.22 & 3.07 & 2.71 & 3.06 & 2.84 & 2.84 & 2.93 & 23 \\
\hline Maintenance of Landscaping & 2.95 & 2.83 & 2.88 & 3.03 & 3.00 & 2.92 & 2.91 & 2.70 & 2.90 & 24 \\
\hline Maintenance and operation of industrial works & 2.63 & 2.21 & 2.84 & 3.22 & 3.42 & 3.00 & 3.09 & 2.52 & 2.89 & 25 \\
\hline Communication technology & 2.93 & 2.72 & 2.94 & 2.88 & 2.94 & 2.98 & 2.76 & 2.68 & 2.86 & 27 \\
\hline Maintenance and oper. of water \& sanitation works & 2.76 & 2.23 & 3.08 & 3.17 & 3.22 & 2.87 & 2.94 & 2.54 & 2.86 & 26 \\
\hline Well drilling & 2.83 & 2.47 & 2.89 & 3.03 & 2.90 & 2.96 & 3.06 & 2.47 & 2.81 & 28 \\
\hline Maintenance and operation dams & 2.75 & 2.31 & 2.90 & 2.80 & 2.88 & 2.99 & 3.22 & 2.48 & 2.80 & 29 \\
\hline Average & 2.95 & 2.80 & 3.10 & 3.12 & 3.23 & 3.06 & 3.05 & 2.75 & 2.95 & \\
\hline Rank & 6 & 7 & 3 & 2 & 1 & 4 & 5 & 8 & & \\
\hline
\end{tabular}

Tables 8-15 shows the count and percentage of respondents in terms of the Likert scale, mean, standard deviation in terms of "mean \pm standard deviation", priority, and response for all subfactors. The tables show the counts (Count) of all respondents with respect to opinions "strongly disagree, disagree, neither, agree, strongly agree) in the third to seventh columns and respondent percentages $(\mathrm{N} \%)$. Column 7 calculates the mean while column 8 determine the standard deviation and column 9 highlights priority and finally column 10 attributes the responses.

Table 16 shows the corresponding values for the overall performance for implementation. Table 8 demonstrates that the mean overall performance in implementing the general requirements of Saudi environmental laws by the construction industry is equal to $2.97 \pm 1.31$. This indicates that the implementation level of the general requirements is difficult to be defined by practitioners and that the environmental protection concepts were not clear to respondents. The respondents agree with F1.1 that the facility has an up-to-date operating license from the government and agree with F1.2 related to the question "Has the facility been cited for any 
environmental violations or been issued any notifications relating to environmental matters, and if so, have the conditions or violations been addressed and subsequently approved or signed off by the appropriate authorities". The response for F1.7 was "Disagree" with a mean $2.36 \pm 1.46$, indicating that the facility did not comply with all applicable regulations and standards when designing or operating any project or activity. The remaining sub-factors performance was "Neither", as shown in the tables.

Table 8. General environmental requirements implementation descriptive statistics

\begin{tabular}{|c|c|c|c|c|c|c|c|c|c|c|}
\hline \multicolumn{2}{|c|}{ Sub-factor } & Strongly & Disagree & Neither & Agree & Strongly & Mean & Std. & Priority & Response \\
\hline F1.1 & $\begin{array}{c}\text { Count } \\
\mathrm{N} \%\end{array}$ & $\begin{array}{c}193 \\
19.3 \%\end{array}$ & $\begin{array}{c}208 \\
20.8 \%\end{array}$ & $\begin{array}{c}242 \\
24.2 \%\end{array}$ & $\begin{array}{c}197 \\
19.7 \%\end{array}$ & $\begin{array}{c}160 \\
16.0 \%\end{array}$ & 2.92 & 1.34 & 4 & Neither \\
\hline $\mathrm{F} 1.2$ & $\begin{array}{c}\text { Count } \\
\mathrm{N} \%\end{array}$ & $\begin{array}{c}157 \\
15.7 \%\end{array}$ & $\begin{array}{c}194 \\
19.4 \%\end{array}$ & $\begin{array}{c}248 \\
24.8 \%\end{array}$ & $\begin{array}{c}221 \\
22.1 \%\end{array}$ & $\begin{array}{c}180 \\
18.0 \%\end{array}$ & 3.07 & 1.32 & 3 & Neither \\
\hline F1.3 & $\begin{array}{c}\text { Count } \\
\mathrm{N} \%\end{array}$ & $\begin{array}{c}22 \\
2.2 \%\end{array}$ & $\begin{array}{c}240 \\
24.0 \%\end{array}$ & $\begin{array}{c}241 \\
24.1 \%\end{array}$ & $\begin{array}{c}252 \\
25.2 \%\end{array}$ & $\begin{array}{c}245 \\
24.5 \%\end{array}$ & 3.46 & 1.16 & 1 & Agree \\
\hline F1.4 & $\begin{array}{c}\text { Count } \\
\mathrm{N} \%\end{array}$ & $\begin{array}{c}5 \\
0.5 \%\end{array}$ & $\begin{array}{c}269 \\
26.9 \%\end{array}$ & $\begin{array}{c}238 \\
23.8 \%\end{array}$ & $\begin{array}{c}263 \\
26.3 \%\end{array}$ & $\begin{array}{c}225 \\
22.5 \%\end{array}$ & 3.43 & 1.12 & 2 & Agree \\
\hline F1.5 & $\begin{array}{c}\text { Count } \\
\mathrm{N} \%\end{array}$ & $\begin{array}{c}197 \\
19.7 \%\end{array}$ & $\begin{array}{c}212 \\
21.2 \%\end{array}$ & $\begin{array}{c}265 \\
26.5 \%\end{array}$ & $\begin{array}{c}261 \\
26.1 \%\end{array}$ & $\begin{array}{c}65 \\
6.5 \%\end{array}$ & 2.79 & 1.21 & 5 & Neither \\
\hline F1.6 & $\begin{array}{c}\text { Count } \\
\mathrm{N} \%\end{array}$ & $\begin{array}{c}193 \\
19.3 \%\end{array}$ & $\begin{array}{c}238 \\
23.8 \%\end{array}$ & $\begin{array}{c}270 \\
27.0 \%\end{array}$ & $\begin{array}{c}243 \\
24.3 \%\end{array}$ & $\begin{array}{c}56 \\
5.6 \%\end{array}$ & 2.73 & 1.18 & 6 & Neither \\
\hline F1.7 & $\begin{array}{c}\text { Count } \\
\mathrm{N} \%\end{array}$ & $\begin{array}{c}401 \\
40.1 \%\end{array}$ & $\begin{array}{c}245 \\
24.5 \%\end{array}$ & $\begin{array}{c}111 \\
11.1 \%\end{array}$ & $\begin{array}{c}83 \\
8.3 \%\end{array}$ & $\begin{array}{c}160 \\
16.0 \%\end{array}$ & 2.36 & 1.46 & 7 & Disagree \\
\hline Totals & $\begin{array}{c}\text { Count } \\
\mathrm{N} \%\end{array}$ & $\begin{array}{c}1168 \\
16.7 \%\end{array}$ & $\begin{array}{c}1606 \\
22.9 \%\end{array}$ & $\begin{array}{c}1615 \\
23.1 \%\end{array}$ & $\begin{array}{c}1520 \\
21.7 \%\end{array}$ & $\begin{array}{c}1091 \\
15.6 \%\end{array}$ & 2.97 & 1.31 & & Neither \\
\hline
\end{tabular}

Table 9 shows the performance of the construction industry in implementing environmental laws, regarding air quality/emissions. The overall performance level was $2.85 \pm 1.35$, indicating that the response was "Neither". The performance for all subfactors was also "Neither", indicating that the respondents could not decide on the level of implementation. The lowest performance level for F2.4, related to "Does the facility ensure that emission of smoke, gases, vapors, and solid or liquid residues resulting from the burning of any kind of fuel or a similar action are within allowable limits permitted in the environmental standards listed under Attachment A of this document?" was a $2.70 \pm 1.37$. F2.5 is related to "Does the facility ensure that there is no leaking or emission of air pollutants into the work place beyond the allowable limits of the environmental standards?". This analysis has priority level of 5 and response result as neither, with a mean of $2.74 \pm 1.42$ which confirms that the company has no proven records about the leakage of emission and air pollutants beyond allowable standard limits.

The overall performance for implementing regulations related to wastewater discharges from the point of view of respondents is "Neither" with a mean of $3.11 \pm 1.30$, as shown in Table 10. The lowest performance was for F3.1, related to whether the various facilities take the necessary precautions to ensure prevention of direct or indirect contamination of surface, ground, and coastal waters that might be caused by solid or liquid residues; and take actions to ensure that the soil and land were preserved and its deterioration and/or contamination was curbed. "Neither" was the 
response to all sub-factors for implementing wastewater-discharge environmental regulations.

Table 9. Air quality/emissions implementation descriptive statistics

\begin{tabular}{|c|c|c|c|c|c|c|c|c|c|c|}
\hline \multicolumn{2}{|c|}{ Sub-factor } & $\begin{array}{l}\text { Strongly } \\
\text { disagree }\end{array}$ & Disagree & Neither & Agree & $\begin{array}{c}\text { Strongly } \\
\text { agree }\end{array}$ & Mean & $\begin{array}{c}\text { Std. } \\
\text { deviation }\end{array}$ & Priority & Response \\
\hline $\mathrm{F} 2.1$ & $\begin{array}{c}\text { Count } \\
\mathrm{N} \%\end{array}$ & $\begin{array}{c}96 \\
9.6 \%\end{array}$ & $\begin{array}{c}258 \\
25.8 \%\end{array}$ & $\begin{array}{c}291 \\
29.1 \%\end{array}$ & $\begin{array}{c}240 \\
24.0 \%\end{array}$ & $\begin{array}{c}115 \\
11.5 \%\end{array}$ & 3.02 & 1.15 & 1 & Neither \\
\hline $\mathrm{F} 2.2$ & $\begin{array}{c}\text { Count } \\
\mathrm{N} \%\end{array}$ & $\begin{array}{c}198 \\
19.8 \%\end{array}$ & $\begin{array}{c}236 \\
23.6 \%\end{array}$ & $\begin{array}{c}243 \\
24.3 \%\end{array}$ & $\begin{array}{c}153 \\
15.3 \%\end{array}$ & $\begin{array}{c}170 \\
17.0 \%\end{array}$ & 2.86 & 1.35 & 4 & Neither \\
\hline F2.3 & $\begin{array}{c}\text { Count } \\
\mathrm{N} \%\end{array}$ & $\begin{array}{c}193 \\
19.3 \%\end{array}$ & $\begin{array}{c}208 \\
20.8 \%\end{array}$ & $\begin{array}{c}242 \\
24.2 \%\end{array}$ & $\begin{array}{c}197 \\
19.7 \%\end{array}$ & $\begin{array}{c}160 \\
16.0 \%\end{array}$ & 2.92 & 1.34 & 2 & Neither \\
\hline F2.4 & $\begin{array}{c}\text { Count } \\
\mathrm{N} \%\end{array}$ & $\begin{array}{c}237 \\
23.7 \%\end{array}$ & $\begin{array}{c}266 \\
26.6 \%\end{array}$ & $\begin{array}{c}221 \\
22.1 \%\end{array}$ & $\begin{array}{c}114 \\
11.4 \%\end{array}$ & $\begin{array}{c}162 \\
16.2 \%\end{array}$ & 2.70 & 1.37 & 6 & Neither \\
\hline $\mathrm{F} 2.5$ & $\begin{array}{c}\text { Count } \\
\mathrm{N} \%\end{array}$ & $\begin{array}{c}258 \\
25.8 \%\end{array}$ & $\begin{array}{c}239 \\
23.9 \%\end{array}$ & $\begin{array}{c}169 \\
16.9 \%\end{array}$ & $\begin{array}{c}175 \\
17.5 \%\end{array}$ & $\begin{array}{c}159 \\
15.9 \%\end{array}$ & 2.74 & 1.42 & 5 & Neither \\
\hline F2.6 & $\begin{array}{c}\text { Count } \\
\mathrm{N} \%\end{array}$ & $\begin{array}{c}234 \\
23.4 \% \\
\end{array}$ & $\begin{array}{c}230 \\
23.0 \%\end{array}$ & $\begin{array}{c}130 \\
13.0 \%\end{array}$ & $\begin{array}{c}246 \\
24.6 \%\end{array}$ & $\begin{array}{c}160 \\
16.0 \%\end{array}$ & 2.87 & 1.42 & 3 & Neither \\
\hline Totals & $\begin{array}{l}\text { Count } \\
\mathrm{N} \%\end{array}$ & $\begin{array}{c}1216 \\
20.3 \%\end{array}$ & $\begin{array}{c}1437 \\
24.0 \%\end{array}$ & $\begin{array}{c}1296 \\
21.6 \%\end{array}$ & $\begin{array}{c}1125 \\
18.8 \%\end{array}$ & $\begin{array}{c}926 \\
15.4 \%\end{array}$ & 2.85 & 1.35 & & Neither \\
\hline
\end{tabular}

Table 10. Wastewater discharges implementation descriptive statistics

\begin{tabular}{|c|c|c|c|c|c|c|c|c|c|c|}
\hline \multicolumn{2}{|c|}{ Sub-factor } & $\begin{array}{l}\text { Strongly } \\
\text { disagree }\end{array}$ & Disagree & Neither & Agree & $\begin{array}{c}\text { Strongly } \\
\text { agree }\end{array}$ & Mean & $\begin{array}{c}\text { Std. } \\
\text { deviation }\end{array}$ & Priority & Response \\
\hline F3.1 & $\begin{array}{l}\text { Count } \\
\mathrm{N} \%\end{array}$ & $\begin{array}{c}181 \\
18.1 \%\end{array}$ & $\begin{array}{c}301 \\
30.1 \%\end{array}$ & $\begin{array}{c}202 \\
20.2 \%\end{array}$ & $\begin{array}{c}174 \\
17.4 \%\end{array}$ & $\begin{array}{c}142 \\
14.2 \%\end{array}$ & 2.80 & 1.31 & 6 & Neither \\
\hline F3.2 & $\begin{array}{l}\text { Count } \\
\mathrm{N} \%\end{array}$ & $\begin{array}{c}104 \\
10.4 \%\end{array}$ & $\begin{array}{c}201 \\
20.1 \%\end{array}$ & $\begin{array}{c}251 \\
25.1 \%\end{array}$ & $\begin{array}{c}301 \\
30.1 \%\end{array}$ & $\begin{array}{c}143 \\
14.3 \%\end{array}$ & 3.18 & 1.20 & 2 & Neither \\
\hline F3.3 & $\begin{array}{c}\text { Count } \\
\mathrm{N} \%\end{array}$ & $\begin{array}{c}109 \\
10.9 \%\end{array}$ & $\begin{array}{c}178 \\
17.8 \%\end{array}$ & $\begin{array}{c}266 \\
26.6 \%\end{array}$ & $\begin{array}{c}288 \\
28.8 \%\end{array}$ & $\begin{array}{c}159 \\
15.9 \%\end{array}$ & 3.21 & 1.22 & 1 & Neither \\
\hline F3.4 & $\begin{array}{c}\text { Count } \\
\mathrm{N} \%\end{array}$ & $\begin{array}{c}120 \\
12.0 \%\end{array}$ & $\begin{array}{c}247 \\
24.7 \%\end{array}$ & $\begin{array}{c}222 \\
22.2 \%\end{array}$ & $\begin{array}{c}190 \\
19.0 \%\end{array}$ & $\begin{array}{c}221 \\
22.1 \%\end{array}$ & 3.15 & 1.33 & 4 & Neither \\
\hline F3.5 & $\begin{array}{c}\text { Count } \\
\mathrm{N} \%\end{array}$ & $\begin{array}{c}141 \\
14.1 \%\end{array}$ & $\begin{array}{c}205 \\
20.5 \%\end{array}$ & $\begin{array}{c}224 \\
22.4 \%\end{array}$ & $\begin{array}{c}199 \\
19.9 \%\end{array}$ & $\begin{array}{c}231 \\
23.1 \%\end{array}$ & 3.17 & 1.36 & 3 & Neither \\
\hline F3.6 & $\begin{array}{c}\text { Count } \\
\mathrm{N} \%\end{array}$ & $\begin{array}{c}139 \\
13.9 \% \\
\end{array}$ & $\begin{array}{c}206 \\
20.6 \% \\
\end{array}$ & $\begin{array}{c}233 \\
23.3 \% \\
\end{array}$ & $\begin{array}{c}232 \\
23.2 \% \\
\end{array}$ & $\begin{array}{c}190 \\
19.0 \% \\
\end{array}$ & 3.13 & 1.31 & 5 & Neither \\
\hline Totals & $\begin{array}{l}\text { Count } \\
\mathrm{N} \%\end{array}$ & $\begin{array}{c}794 \\
13.2 \%\end{array}$ & $\begin{array}{c}1338 \\
22.3 \%\end{array}$ & $\begin{array}{c}1398 \\
23.3 \%\end{array}$ & $\begin{array}{c}1384 \\
23.1 \%\end{array}$ & $\begin{array}{c}1086 \\
18.1 \%\end{array}$ & 3.11 & 1.30 & & Neither \\
\hline
\end{tabular}

Table 11 summarizes the performance of hazardous waste management regulation implementation. It indicates that the overall mean is $3.12 \pm 1.26$, and that the implementation scale is "Neither". As shown in the table, the implementing of environmental regulations for this factor ranges from 3.27 for F4.3 to $3.01 \pm 0.26$ for F4.4 indicates the extreme keenness of the Kingdom's institutions in the construction industry that deal with hazardous materials.

The performance regarding radioactive materials handling and disposal (shown in Table 12) indicates an implementation level mean of $3.23 \pm 1.35$, and a small range of 0.02 between F5.1 and F5.2, due to the nature of materials that may cause severe chronic diseases and affect the health of individuals and workers. The main reason for the increased percentage of disagree in F5.2 "storage, treatment, recycling, and 
transportation of radioactive waste in accordance to regulations" is due to the nature of the radioactive waste in Saudi Arabia resulting from water treatment with the acceptable levels and controlled completely with the Saudi governmental specialized agencies. The inspection team totally ignore, because used in lower levels and it is within the radioactive acceptable limits zone of disposal standards, but the engineers in and around the company feel that it is disposed with not following the standards.

Table 11. Hazardous waste management implementation descriptive statistics

\begin{tabular}{|c|c|c|c|c|c|c|c|c|c|c|}
\hline \multicolumn{2}{|c|}{ Sub-factor } & Strongly & Disagree & Neither & Agree & Strongly & Mean & Std. & Priority & Response \\
\hline $\mathrm{F} 4.1$ & $\begin{array}{c}\text { Count } \\
\mathrm{N} \%\end{array}$ & $\begin{array}{c}161 \\
16.1 \%\end{array}$ & $\begin{array}{c}204 \\
20.4 \%\end{array}$ & $\begin{array}{c}185 \\
18.5 \%\end{array}$ & $\begin{array}{c}241 \\
24.1 \%\end{array}$ & $\begin{array}{c}209 \\
20.9 \%\end{array}$ & 3.13 & 1.38 & 5 & Neither \\
\hline $\mathrm{F} 4.2$ & $\begin{array}{l}\text { Count } \\
\mathrm{N} \%\end{array}$ & $\begin{array}{c}165 \\
16.5 \%\end{array}$ & $\begin{array}{c}156 \\
15.6 \%\end{array}$ & $\begin{array}{c}211 \\
21.1 \%\end{array}$ & $\begin{array}{c}272 \\
27.2 \%\end{array}$ & $\begin{array}{c}196 \\
19.6 \%\end{array}$ & 3.18 & 1.35 & 2 & Neither \\
\hline $\mathrm{F} 4.3$ & $\begin{array}{c}\text { Count } \\
\mathrm{N} \%\end{array}$ & $\begin{array}{c}86 \\
8.6 \%\end{array}$ & $\begin{array}{c}186 \\
18.6 \%\end{array}$ & $\begin{array}{c}271 \\
27.1 \%\end{array}$ & $\begin{array}{c}289 \\
28.9 \%\end{array}$ & $\begin{array}{c}168 \\
16.8 \%\end{array}$ & 3.27 & 1.19 & 1 & Neither \\
\hline $\mathrm{F} 4.4$ & $\begin{array}{c}\text { Count } \\
\mathrm{N} \%\end{array}$ & $\begin{array}{c}94 \\
9.4 \%\end{array}$ & $\begin{array}{c}264 \\
26.4 \%\end{array}$ & $\begin{array}{c}314 \\
31.4 \%\end{array}$ & $\begin{array}{c}195 \\
19.5 \%\end{array}$ & $\begin{array}{c}133 \\
13.3 \%\end{array}$ & 3.01 & 1.17 & 7 & Neither \\
\hline $\mathrm{F} 4.5$ & $\begin{array}{c}\text { Count } \\
\mathrm{N} \%\end{array}$ & $\begin{array}{c}107 \\
10.7 \%\end{array}$ & $\begin{array}{c}231 \\
23.1 \%\end{array}$ & $\begin{array}{c}258 \\
25.8 \%\end{array}$ & $\begin{array}{c}255 \\
25.5 \%\end{array}$ & $\begin{array}{c}149 \\
14.9 \%\end{array}$ & 3.11 & 1.22 & 3 & Neither \\
\hline F4.6 & $\begin{array}{c}\text { Count } \\
\mathrm{N} \%\end{array}$ & $\begin{array}{c}137 \\
13.7 \%\end{array}$ & $\begin{array}{c}245 \\
24.5 \%\end{array}$ & $\begin{array}{c}240 \\
24.0 \%\end{array}$ & $\begin{array}{c}180 \\
18.0 \%\end{array}$ & $\begin{array}{c}198 \\
19.8 \%\end{array}$ & 3.06 & 1.32 & 6 & Neither \\
\hline $\mathrm{F} 4.7$ & $\begin{array}{c}\text { Count } \\
\mathrm{N} \%\end{array}$ & $\begin{array}{c}94 \\
9.4 \%\end{array}$ & $\begin{array}{c}192 \\
19.2 \%\end{array}$ & $\begin{array}{c}344 \\
34.4 \%\end{array}$ & $\begin{array}{c}247 \\
24.7 \%\end{array}$ & $\begin{array}{c}123 \\
12.3 \%\end{array}$ & 3.11 & 1.13 & 4 & Neither \\
\hline Totals & $\begin{array}{l}\text { Count } \\
\mathrm{N} \%\end{array}$ & $\begin{array}{c}844 \\
12.1 \%\end{array}$ & $\begin{array}{r}1478 \\
21.1 \%\end{array}$ & $\begin{array}{c}1823 \\
26.0 \%\end{array}$ & $\begin{array}{r}1679 \\
24.0 \%\end{array}$ & $\begin{array}{c}1176 \\
16.8 \%\end{array}$ & 3.12 & 1.26 & & Neither \\
\hline
\end{tabular}

Table 12. Radioactive materials handling and disposal implementation descriptive statistics

\begin{tabular}{c|c|c|c|c|c|c|c|c|c|c}
\hline \multicolumn{2}{c|}{ Sub-factor } & $\begin{array}{c}\text { Strongly } \\
\text { disagree }\end{array}$ & Disagree & Neither & Agree & $\begin{array}{c}\text { Strongly } \\
\text { agree }\end{array}$ & Mean & $\begin{array}{c}\text { Std. } \\
\text { deviation }\end{array}$ & Priority & Response \\
\hline \multirow{2}{*}{ F5.1 } & Count & 132 & 199 & 184 & 263 & 222 & 3.24 & 1.34 & 1 & Neither \\
& N $\%$ & $13.2 \%$ & $19.9 \%$ & $18.4 \%$ & $26.3 \%$ & $22.2 \%$ & & & & \\
F5.2 & Count & 130 & 201 & 229 & 200 & 240 & 3.22 & 1.35 & 2 & Neither \\
& N \% & $13.0 \%$ & $20.1 \%$ & $22.9 \%$ & $20.0 \%$ & $24.0 \%$ & & & \\
\hline \multirow{2}{*}{ Totals } & Count & 262 & 400 & 413 & 463 & 462 & 3.23 & 1.35 & & Neither \\
& N \% & $13.1 \%$ & $20.0 \%$ & $20.7 \%$ & $23.2 \%$ & $23.1 \%$ & & & & \\
\hline
\end{tabular}

Table 13 shows the implementation level of hazardous or dangerous substance compliance-program implementation. The performance of implementation had a mean of $3.07 \pm 1.30$, and the overall performance is "Neither". The lowest implementation level is for F6.1, related to the existence of a listing of all dangerous chemical substances used at the facility on-site $(2.75 \pm 1.05$ and a "Neither" response).

Table 14 demonstrates the extent to which the companies apply environmental noise laws and whether they take the necessary precautions to ensure that noise levels do not exceed permissible/standard environmental limits. The overall average performance measure for this factor was $3.05 \pm 1$.

Table 15 shows the implementation level of Saudi companies for the emergency planning factor. It shows that the average overall performance is $2.78 \pm 1.28$. Sub-factor F8.1 represents the opinion of the participants in the field study whether the facility has the 
potential to cause adverse impacts on the environment, and if so, whether the facility has prepared emergency plans to prevent or alleviate the hazards of such impacts, and finally whether the facility has enough means to implement these plans. The average opinion of the participants was $2.80 \pm 1.28$, representing a "Neither" response. The reason for this evaluation might be explained by the fact that the responsibility to deal with emergency cases was assigned to the Saudi General Directorate of Civil Defense and thus, that the emergency work was not assigned to the industrial organization itself. The lowest performance was assigned to F8.4 $(2.59 \pm 1.18)$ with a "Disagree" response in relation to "Has the facility verified plans required for environmental protection from pollution resulting from conducted projects, and periodically reviewed these plans to coordinate efforts for their implementation?"

Table 17 shows the one-way ANOVA for the for environmental law implementation by field of construction industry. It shows the mean, standard deviation, standard error, $95 \%$ confidence interval for the mean, test of homogeneity of variances, ANOVA' $F$ and significance, and the statistical significance for each factor. From this table, we conclude that there is no homogeneity between samples of the implementation levels for F1.3, F1.4, F1.6, F1.7, F2.1, F2.2, F2.4, F2.5, F3.1, F4.2, F4.3, F4.4, F4.5, F4.7, F5.1, F6.1, F6.3, F6.4, F6.5, F6.6, F7.2, F7.3, F8.1, F8.3, F8.4, F8.5, F8.6, F8.8, F8.9, F8.10, F8.11, and F8.12, wherein the values of $\mathrm{F}<0.05$; therefore, the ANOVA test cannot be completed. However, the ANOVA can be completed for the remaining factors. Judgment for non-homogeneity is based on calculating the Levene's test and corresponding significance level of $<0.05$.

Moreover, the one-way ANOVA test for F3.2, F3.3, and F8.2 demonstrates that homogeneity of samples does exist and consequently, there is a difference between the implementation levels of the environmental laws in all 29 construction industry fields with mean levels of 3.18, 3.12, and 3.06.

The significance value for ANOVA regarding F1.1, F1.2, F1.5, F2.3, F2.6, F3.4, F3.5, F3.6, F4.1, F4.6, F5.2, F6.2, F7.1, and F8.7 was >0.05, indicating that there is no statistical evidence that there is a difference between the implementation levels for the corresponding factors. The main results obtained from this research are supporting the work done in China by Wang (2013) and van Zeben (2014) as they highlighted the importance of monitoring the environmental laws implementation not by enforcement but by societal involvement.

Table 13. Hazardous/dangerous substance compliance programs implementation descriptive statistics

\begin{tabular}{|c|c|c|c|c|c|c|c|c|c|c|}
\hline \multicolumn{2}{|c|}{ Sub-factor } & $\begin{array}{l}\text { Strongly } \\
\text { disagree }\end{array}$ & Disagree & Neither & Agree & Strongly & Mean & Std. & Priority & Response \\
\hline F6.1 & $\begin{array}{l}\text { Count } \\
\mathrm{N} \%\end{array}$ & $\begin{array}{c}112 \\
11.2 \%\end{array}$ & $\begin{array}{c}302 \\
30.2 \%\end{array}$ & $\begin{array}{c}395 \\
39.5 \%\end{array}$ & $\begin{array}{c}111 \\
11.1 \%\end{array}$ & $\begin{array}{c}80 \\
8.0 \%\end{array}$ & 2.75 & 1.05 & 6 & Neither \\
\hline F6.2 & $\begin{array}{c}\text { Count } \\
\mathrm{N} \%\end{array}$ & $\begin{array}{c}193 \\
19.3 \%\end{array}$ & $\begin{array}{c}208 \\
20.8 \%\end{array}$ & $\begin{array}{c}242 \\
24.2 \%\end{array}$ & $\begin{array}{c}356 \\
35.6 \%\end{array}$ & $\begin{array}{c}1 \\
.1 \%\end{array}$ & 2.76 & 1.13 & 5 & Neither \\
\hline F6.3 & $\begin{array}{c}\text { Count } \\
\mathrm{N} \%\end{array}$ & $\begin{array}{c}146 \\
14.6 \%\end{array}$ & $\begin{array}{c}186 \\
18.6 \%\end{array}$ & $\begin{array}{c}193 \\
19.3 \%\end{array}$ & $\begin{array}{c}255 \\
25.5 \%\end{array}$ & $\begin{array}{c}220 \\
22.0 \%\end{array}$ & 3.22 & 1.36 & 2 & Neither \\
\hline F6.4 & $\begin{array}{l}\text { Count } \\
\mathrm{N} \%\end{array}$ & $\begin{array}{c}173 \\
17.3 \%\end{array}$ & $\begin{array}{c}147 \\
14.7 \%\end{array}$ & $\begin{array}{c}231 \\
23.1 \%\end{array}$ & $\begin{array}{c}201 \\
20.1 \%\end{array}$ & $\begin{array}{c}248 \\
24.8 \%\end{array}$ & 3.20 & 1.41 & 3 & Neither \\
\hline F6.5 & $\begin{array}{c}\text { Count } \\
\mathrm{N} \%\end{array}$ & $\begin{array}{c}132 \\
13.2 \%\end{array}$ & $\begin{array}{c}132 \\
13.2 \%\end{array}$ & $\begin{array}{c}266 \\
26.6 \%\end{array}$ & $\begin{array}{c}242 \\
24.2 \%\end{array}$ & $\begin{array}{c}228 \\
22.8 \%\end{array}$ & 3.30 & 1.31 & 1 & Neither \\
\hline F6.6 & $\begin{array}{c}\text { Count } \\
\mathrm{N} \%\end{array}$ & $\begin{array}{c}146 \\
14.6 \%\end{array}$ & $\begin{array}{c}187 \\
18.7 \%\end{array}$ & $\begin{array}{c}219 \\
21.9 \%\end{array}$ & $\begin{array}{c}202 \\
20.2 \%\end{array}$ & $\begin{array}{c}246 \\
24.6 \%\end{array}$ & 3.21 & 1.38 & 4 & Neither \\
\hline Totals & $\begin{array}{c}\text { Count } \\
\mathrm{N} \%\end{array}$ & $\begin{array}{c}902 \\
15.0 \%\end{array}$ & $\begin{array}{c}1162 \\
19.4 \%\end{array}$ & $\begin{array}{c}1546 \\
25.8 \%\end{array}$ & $\begin{array}{c}1367 \\
22.8 \%\end{array}$ & $\begin{array}{c}1023 \\
17.1 \%\end{array}$ & 3.07 & 1.30 & & Neither \\
\hline
\end{tabular}


Table 14. Environmental noise implementation descriptive statistics

\begin{tabular}{|c|c|c|c|c|c|c|c|c|c|c|}
\hline \multicolumn{2}{|c|}{ Sub-factor } & $\begin{array}{l}\text { Strongly } \\
\text { disagree }\end{array}$ & Disagree & Neither & Agree & $\begin{array}{c}\text { Strongly } \\
\text { agree }\end{array}$ & Mean & $\begin{array}{c}\text { Std. } \\
\text { deviation }\end{array}$ & Priority & Response \\
\hline F7.1 & $\begin{array}{c}\text { Count } \\
\mathrm{N} \%\end{array}$ & $\begin{array}{c}129 \\
12.9 \%\end{array}$ & $\begin{array}{c}204 \\
20.4 \%\end{array}$ & $\begin{array}{c}208 \\
20.8 \%\end{array}$ & $\begin{array}{c}250 \\
25.0 \%\end{array}$ & $\begin{array}{c}209 \\
20.9 \%\end{array}$ & 3.21 & 1.32 & 1 & Neither \\
\hline F7.2 & $\begin{array}{c}\text { Count } \\
\mathrm{N} \%\end{array}$ & $\begin{array}{c}151 \\
15.1 \%\end{array}$ & $\begin{array}{c}244 \\
24.4 \%\end{array}$ & $\begin{array}{c}207 \\
20.7 \%\end{array}$ & $\begin{array}{c}192 \\
19.2 \%\end{array}$ & $\begin{array}{c}206 \\
20.6 \%\end{array}$ & 3.06 & 1.36 & 2 & Neither \\
\hline F7.3 & $\begin{array}{c}\text { Count } \\
\mathrm{N} \%\end{array}$ & $\begin{array}{c}199 \\
19.9 \%\end{array}$ & $\begin{array}{c}185 \\
18.5 \%\end{array}$ & $\begin{array}{c}262 \\
26.2 \%\end{array}$ & $\begin{array}{c}235 \\
23.5 \%\end{array}$ & $\begin{array}{c}119 \\
11.9 \%\end{array}$ & 2.89 & 1.29 & 3 & Neither \\
\hline Totals & $\begin{array}{c}\text { Count } \\
\mathrm{N} \%\end{array}$ & $\begin{array}{c}479 \\
16.0 \%\end{array}$ & $\begin{array}{c}633 \\
21.1 \%\end{array}$ & $\begin{array}{c}677 \\
22.6 \%\end{array}$ & $\begin{array}{c}677 \\
22.6 \%\end{array}$ & $\begin{array}{c}534 \\
17.8 \%\end{array}$ & 3.05 & 1.33 & & Neither \\
\hline
\end{tabular}

Table 15. External emergency planning implementation descriptive statistics

\begin{tabular}{|c|c|c|c|c|c|c|c|c|c|c|}
\hline \multicolumn{2}{|c|}{ Sub-factor } & Strongly & Disagree & Neither & Agree & Strongly & Mean & Std. & Priority & Response \\
\hline F8.1 & $\begin{array}{c}\text { Count } \\
\mathrm{N} \%\end{array}$ & $\begin{array}{c}209 \\
20.9 \%\end{array}$ & $\begin{array}{c}220 \\
22.0 \%\end{array}$ & $\begin{array}{c}229 \\
22.9 \%\end{array}$ & $\begin{array}{c}246 \\
24.6 \%\end{array}$ & $\begin{array}{c}96 \\
9.6 \%\end{array}$ & 2.80 & 1.28 & 6 & Neither \\
\hline F8.2 & $\begin{array}{c}\text { Count } \\
\text { N \% }\end{array}$ & $\begin{array}{c}190 \\
19.0 \%\end{array}$ & $\begin{array}{c}143 \\
14.3 \%\end{array}$ & $\begin{array}{c}237 \\
23.7 \%\end{array}$ & $\begin{array}{c}276 \\
27.6 \%\end{array}$ & $\begin{array}{c}154 \\
15.4 \%\end{array}$ & 3.06 & 1.33 & 2 & Neither \\
\hline F8.3 & $\begin{array}{c}\text { Count } \\
\text { N \% }\end{array}$ & $\begin{array}{c}216 \\
21.6 \%\end{array}$ & $\begin{array}{c}280 \\
28.0 \%\end{array}$ & $\begin{array}{c}254 \\
25.4 \%\end{array}$ & $\begin{array}{c}166 \\
16.6 \%\end{array}$ & $\begin{array}{c}84 \\
8.4 \%\end{array}$ & 2.62 & 1.22 & 11 & Neither \\
\hline F8.4 & $\begin{array}{c}\text { Count } \\
\mathrm{N} \%\end{array}$ & $\begin{array}{c}210 \\
21.0 \%\end{array}$ & $\begin{array}{c}290 \\
29.0 \%\end{array}$ & $\begin{array}{c}277 \\
27.7 \%\end{array}$ & $\begin{array}{c}151 \\
15.1 \%\end{array}$ & $\begin{array}{c}72 \\
7.2 \%\end{array}$ & 2.59 & 1.18 & 12 & Disagree \\
\hline F8_5 & $\begin{array}{c}\text { Count } \\
\text { N \% }\end{array}$ & $\begin{array}{c}172 \\
17.2 \%\end{array}$ & $\begin{array}{c}202 \\
20.2 \%\end{array}$ & $\begin{array}{c}241 \\
24.1 \%\end{array}$ & $\begin{array}{c}167 \\
16.7 \%\end{array}$ & $\begin{array}{c}218 \\
21.8 \%\end{array}$ & 3.06 & 1.38 & 1 & Neither \\
\hline F8.6 & $\begin{array}{c}\text { Count } \\
\text { N \% }\end{array}$ & $\begin{array}{c}212 \\
21.2 \%\end{array}$ & $\begin{array}{c}240 \\
24.0 \%\end{array}$ & $\begin{array}{c}214 \\
21.4 \%\end{array}$ & $\begin{array}{c}207 \\
20.7 \%\end{array}$ & $\begin{array}{c}127 \\
12.7 \%\end{array}$ & 2.80 & 1.32 & 5 & Neither \\
\hline F8.7 & $\begin{array}{c}\text { Count } \\
\text { N \% }\end{array}$ & $\begin{array}{c}224 \\
22.4 \%\end{array}$ & $\begin{array}{c}274 \\
27.4 \%\end{array}$ & $\begin{array}{c}235 \\
23.5 \%\end{array}$ & $\begin{array}{c}165 \\
16.5 \%\end{array}$ & $\begin{array}{c}102 \\
10.2 \%\end{array}$ & 2.65 & 1.27 & 9 & Neither \\
\hline F8.8 & $\begin{array}{c}\text { Count } \\
\text { N \% }\end{array}$ & $\begin{array}{c}216 \\
21.6 \%\end{array}$ & $\begin{array}{c}266 \\
26.6 \%\end{array}$ & $\begin{array}{c}255 \\
25.5 \%\end{array}$ & $\begin{array}{c}193 \\
19.3 \%\end{array}$ & $\begin{array}{c}70 \\
7.0 \%\end{array}$ & 2.64 & 1.21 & 10 & Neither \\
\hline F8.9 & $\begin{array}{c}\text { Count } \\
\text { N \% }\end{array}$ & $\begin{array}{c}208 \\
20.8 \%\end{array}$ & $\begin{array}{c}246 \\
24.6 \%\end{array}$ & $\begin{array}{c}247 \\
24.7 \%\end{array}$ & $\begin{array}{c}170 \\
17.0 \%\end{array}$ & $\begin{array}{c}129 \\
12.9 \%\end{array}$ & 2.77 & 1.30 & 7 & Neither \\
\hline F8.10 & $\begin{array}{c}\text { Count } \\
\text { N \% }\end{array}$ & $\begin{array}{c}214 \\
21.4 \%\end{array}$ & $\begin{array}{c}277 \\
27.7 \%\end{array}$ & $\begin{array}{c}242 \\
24.2 \%\end{array}$ & $\begin{array}{c}181 \\
18.1 \%\end{array}$ & $\begin{array}{c}86 \\
8.6 \%\end{array}$ & 2.65 & 1.23 & 8 & Neither \\
\hline F8.11 & $\begin{array}{c}\text { Count } \\
\mathrm{N} \%\end{array}$ & $\begin{array}{c}159 \\
15.9 \%\end{array}$ & $\begin{array}{c}285 \\
28.5 \%\end{array}$ & $\begin{array}{c}258 \\
25.8 \%\end{array}$ & $\begin{array}{c}180 \\
18.0 \%\end{array}$ & $\begin{array}{c}118 \\
11.8 \%\end{array}$ & 2.81 & 1.24 & 4 & Neither \\
\hline F8.12 & $\begin{array}{l}\text { Count } \\
\text { N \% }\end{array}$ & $\begin{array}{c}166 \\
16.6 \%\end{array}$ & $\begin{array}{c}262 \\
26.2 \%\end{array}$ & $\begin{array}{c}235 \\
23.5 \%\end{array}$ & $\begin{array}{c}197 \\
19.7 \%\end{array}$ & $\begin{array}{c}140 \\
14.0 \%\end{array}$ & 2.88 & 1.29 & 3 & Neither \\
\hline Totals & $\begin{array}{c}\text { Count } \\
\text { N \% }\end{array}$ & $\begin{array}{c}2396 \\
20.0 \%\end{array}$ & $\begin{array}{c}2985 \\
24.9 \%\end{array}$ & $\begin{array}{c}2924 \\
24.4 \%\end{array}$ & $\begin{array}{c}2299 \\
19.2 \%\end{array}$ & $\begin{array}{c}1396 \\
11.6 \%\end{array}$ & 2.78 & 1.28 & & Neither \\
\hline
\end{tabular}

Table 16. Overall environmental laws implementation descriptive statistics

\begin{tabular}{c|c|c|c|c|c|c|c|c|c|c}
\hline \multicolumn{2}{c|}{$\begin{array}{c}\text { Overall } \\
\text { performance }\end{array}$} & $\begin{array}{c}\text { Strongly } \\
\text { disagree }\end{array}$ & Disagree & Neither & Agree & $\begin{array}{c}\text { Strongly } \\
\text { agree }\end{array}$ & Mean & $\begin{array}{c}\text { Std. } \\
\text { deviation }\end{array}$ & Priority & Response \\
\hline \multirow{2}{*}{ Totals } & Count & 8061 & 11039 & 11692 & 10514 & 7694 & 2.95 & 1.13 & & Neither \\
& N \% & $16.5 \%$ & $22.5 \%$ & $23.9 \%$ & $21.5 \%$ & $15.7 \%$ & & & \\
\hline
\end{tabular}


Table 17. One-way ANOVA for environmental law implementation by field of construction industry

\begin{tabular}{|c|c|c|c|c|c|c|c|c|c|c|}
\hline \multirow{2}{*}{$\begin{array}{l}\text { Environmental } \\
\text { law }\end{array}$} & \multirow{2}{*}{ Mean } & \multirow{2}{*}{$\begin{array}{c}\text { Std. } \\
\text { deviation }\end{array}$} & \multirow{2}{*}{$\begin{array}{l}\text { Std. } \\
\text { error }\end{array}$} & \multicolumn{2}{|c|}{$\begin{array}{l}95 \% \text { Confidence interval } \\
\text { for mean }\end{array}$} & \multicolumn{2}{|c|}{$\begin{array}{c}\text { Test of homogeneity } \\
\text { of variances }\end{array}$} & \multicolumn{2}{|c|}{ ANOVA } & \multirow{2}{*}{$\begin{array}{c}\text { Statistical } \\
\text { significance }\end{array}$} \\
\hline & & & & $\begin{array}{l}\text { Lower } \\
\text { bound }\end{array}$ & $\begin{array}{l}\text { Upper } \\
\text { bound }\end{array}$ & $\begin{array}{l}\text { Levene's } \\
\text { statistic }\end{array}$ & Sig. & $\mathbf{F}$ & Sig. & \\
\hline F1.1 & 2.92 & 1.34 & 0.043 & 2.84 & 3.01 & 1.24 & 0.176 & 0.69 & 0.884 & Insignificant \\
\hline $\mathrm{F} 1.2$ & 3.07 & 1.32 & 0.042 & 2.99 & 3.16 & 1.24 & 0.177 & 0.83 & 0.707 & Insignificant \\
\hline F1.3 & 3.46 & 1.16 & 0.037 & 3.39 & 3.53 & 1.90 & 0.003 & -- & -- & -- \\
\hline F1.4 & 3.43 & 1.12 & 0.036 & 3.36 & 3.50 & 1.77 & 0.008 & -- & -- & -- \\
\hline F1.5 & 2.79 & 1.21 & 0.038 & 2.71 & 2.86 & 1.15 & 0.262 & 0.77 & 0.791 & Insignificant \\
\hline F1.6 & 2.73 & 1.18 & 0.037 & 2.66 & 2.80 & 1.88 & 0.004 & -- & -- & -- \\
\hline F1.7 & 2.36 & 1.46 & 0.046 & 2.26 & 2.45 & 3.72 & 0.000 & -- & -- & -- \\
\hline F2.1 & 3.02 & 1.15 & 0.037 & 2.95 & 3.09 & 2.24 & 0.000 & -- & -- & -- \\
\hline F2.2 & 2.86 & 1.35 & 0.043 & 2.78 & 2.95 & 2.79 & 0.000 & -- & -- & -- \\
\hline $\mathrm{F} 2.3$ & 2.92 & 1.34 & 0.043 & 2.84 & 3.01 & 1.24 & 0.176 & 0.69 & 0.884 & Insignificant \\
\hline F2.4 & 2.70 & 1.37 & 0.043 & 2.61 & 2.78 & 9.68 & 0.000 & -- & -- & -- \\
\hline F2.5 & 2.74 & 1.42 & 0.045 & 2.65 & 2.83 & 2.66 & 0.000 & -- & -- & -- \\
\hline F2.6 & 2.87 & 1.42 & 0.045 & 2.78 & 2.96 & 1.72 & 0.011 & 1.33 & 0.116 & Insignificant \\
\hline F3.1 & 2.80 & 1.31 & 0.042 & 2.71 & 2.88 & 4.99 & 0.000 & -- & -- & -- \\
\hline F3.2 & 3.18 & 1.20 & 0.038 & 3.10 & 3.25 & 1.37 & 0.096 & 2.66 & 0.000 & Significant \\
\hline F3.3 & 3.21 & 1.22 & 0.039 & 3.13 & 3.29 & 1.47 & 0.055 & 1.51 & 0.042 & Significant \\
\hline F3.4 & 3.15 & 1.33 & 0.042 & 3.06 & 3.23 & 0.60 & 0.950 & 1.00 & 0.466 & Insignificant \\
\hline F3.5 & 3.17 & 1.36 & 0.043 & 3.09 & 3.26 & 1.73 & 0.010 & 0.90 & 0.616 & Insignificant \\
\hline F3.6 & 3.13 & 1.31 & 0.042 & 3.05 & 3.21 & 1.65 & 0.018 & 1.00 & 0.453 & Insignificant \\
\hline F4.1 & 3.13 & 1.38 & 0.044 & 3.05 & 3.22 & 1.17 & 0.243 & 0.71 & 0.859 & Insignificant \\
\hline F4.2 & 3.18 & 1.35 & 0.043 & 3.09 & 3.26 & 2.61 & 0.000 & -- & -- & -- \\
\hline F4.3 & 3.27 & 1.19 & 0.038 & 3.19 & 3.34 & 2.27 & 0.000 & -- & -- & -- \\
\hline F4.4 & 3.01 & 1.17 & 0.037 & 2.94 & 3.08 & 2.08 & 0.001 & -- & -- & -- \\
\hline F4.5 & 3.11 & 1.22 & 0.039 & 3.03 & 3.18 & 2.70 & 0.000 & -- & -- & -- \\
\hline F4.6 & 3.06 & 1.32 & 0.042 & 2.97 & 3.14 & 1.70 & 0.013 & 0.82 & 0.725 & Insignificant \\
\hline $\mathrm{F} 4.7$ & 3.11 & 1.13 & 0.036 & 3.04 & 3.18 & 1.87 & 0.004 & -- & -- & -- \\
\hline F5.1 & 3.24 & 1.34 & 0.043 & 3.16 & 3.33 & 1.80 & 0.007 & -- & -- & -- \\
\hline F5.2 & 3.22 & 1.35 & 0.043 & 3.13 & 3.30 & 1.52 & 0.041 & 1.29 & 0.143 & Insignificant \\
\hline F6.1 & 2.75 & 1.05 & 0.033 & 2.68 & 2.81 & 12.08 & 0.000 & -- & -- & -- \\
\hline F6.2 & 2.76 & 1.13 & 0.036 & 2.69 & 2.83 & 0.97 & 0.509 & 0.55 & 0.970 & Insignificant \\
\hline F6.3 & 3.22 & 1.36 & 0.043 & 3.13 & 3.30 & 3.92 & 0.000 & -- & -- & -- \\
\hline F6.4 & 3.20 & 1.41 & 0.045 & 3.12 & 3.29 & 2.05 & 0.001 & -- & -- & -- \\
\hline F6.5 & 3.30 & 1.31 & 0.042 & 3.22 & 3.38 & 2.92 & 0.000 & -- & -- & -- \\
\hline F6.6 & 3.22 & 1.38 & 0.044 & 3.13 & 3.30 & 2.08 & 0.001 & -- & -- & -- \\
\hline F7.1 & 3.21 & 1.32 & 0.042 & 3.12 & 3.29 & 1.25 & 0.174 & 0.72 & 0.854 & Insignificant \\
\hline F7.2 & 3.06 & 1.36 & 0.043 & 2.97 & 3.14 & 2.49 & 0.000 & -- & -- & -- \\
\hline F7.3 & 2.89 & 1.29 & 0.041 & 2.81 & 2.97 & 2.58 & 0.000 & -- & -- & -- \\
\hline F8.1 & 2.80 & 1.28 & 0.041 & 2.72 & 2.88 & 5.15 & 0.000 & -- & -- & -- \\
\hline F8.2 & 3.06 & 1.33 & 0.042 & 2.98 & 3.14 & 1.22 & 0.194 & 1.95 & 0.002 & Significant \\
\hline F8.3 & 2.62 & 1.22 & 0.039 & 2.55 & 2.70 & 2.10 & 0.001 & -- & -- & -- \\
\hline F8.4 & 2.59 & 1.18 & 0.037 & 2.51 & 2.66 & 2.85 & 0.000 & -- & -- & -- \\
\hline F8.5 & 3.06 & 1.38 & 0.044 & 2.97 & 3.14 & 19.01 & 0.000 & -- & -- & -- \\
\hline F8.6 & 2.80 & 1.32 & 0.042 & 2.71 & 2.88 & 10.35 & 0.000 & -- & -- & -- \\
\hline F8.7 & 2.65 & 1.27 & 0.040 & 2.57 & 2.73 & 0.87 & 0.658 & 1.01 & 0.442 & Insignificant \\
\hline F8.8 & 2.64 & 1.21 & 0.038 & 2.56 & 2.71 & 2.03 & 0.001 & -- & -- & -- \\
\hline F8.9 & 2.77 & 1.30 & 0.041 & 2.68 & 2.85 & 10.03 & 0.000 & -- & -- & -- \\
\hline F8.10 & 2.65 & 1.23 & 0.039 & 2.57 & 2.72 & 1.78 & 0.007 & -- & -- & -- \\
\hline F8.11 & 2.81 & 1.24 & 0.039 & 2.74 & 2.89 & 12.74 & 0.000 & -- & -- & -- \\
\hline F8.12 & 2.88 & 1.29 & 0.041 & 2.80 & 2.96 & 2.24 & 0.000 & -- & -- & -- \\
\hline
\end{tabular}




\section{Conclusions}

The aim of this research was to investigate the environmental legitimacy implementation in the Saudi Arabian construction industry. To do this, eight regulation categories, each including a set of sub-laws, were defined: general environmental requirements, radioactive materials handling and disposal, hazardous/dangerous substance compliance programs, air quality/emissions, environmental noise, wastewater discharges, external emergency planning, and hazardous waste management. An analytical statistical approach was used to describe and analyze the data set collected in a newly designed Likert 5-scale questionnaire distributed to 1000 organizations that work in the construction industry in 13 regions in Saudi Arabia. These were filled out (through direct meeting with via email) by engineers and professionals, authorized contractors, unauthorized contractors, individuals, and officials and owners. The analysis was done using measures of descriptive statistics, Cronbach's alpha, Pearson correlation coefficient, ANOVA, and the Levene's test (which was used to measure homogeneities between sample groups). The main purpose was to answer the following questions: "Does the construction facility applies the set of environmental regulations or not?" and "Does the construction facility applies the regulations for each law or not?" The levels of implementation were also indicated.

The main finding of this research was that the mean implementation performance was 2.95, indicating a Likert scale of "Neither". This indicates that the participants had difficulty defining accurate answers regarding environmental legitimacy implementation in the Saudi Arabian construction industry. The implementation levels for all eight sub-regulations were defined as "Neither". The one-way ANOVA test for F3.2, F3.3, and F8.2 demonstrates that homogeneity of samples existed and, consequently, that there was a difference between the implementation levels of the environmental laws in all 29 construction industry fields (mean levels of 3.18, 3.12, and 3.06). The significance value (>0.05) for ANOVA regarding F1.1, F1.2, F1.5, F2.3, F2.6, F3.4, F3.5, F3.6, F4.1, F4.6, F5.2, F6.2, F7.1, and F8.7 indicated that there is no statistical evidence that there is a difference between the implementation levels for the corresponding factors. The remaining sub-regulations do not appear to exhibit sample homogeneities according to the Levene's test, so ANOVA could not be conducted. The means for the eight regulation categories (arranged from highest to lowest) for radioactive materials handling and disposal, hazardous waste management, wastewater discharges, hazardous and dangerous substance compliance programs, environmental noise, general environmental requirements, air quality emissions, and external emergency planning were $3.23,3.12,3.10,3.06,3.05,2.95,2.80$, and 2.75 , respectively. This performance level could be explained by the existence of multiple systems related to the environment, the conflict of competencies between the government agencies concerned with the environment, and the failure to activate the current environmental legislation to the appropriate extent. The results of this research are in consistence with the work done by Wang (2013) and van Zeben (2014) in China.

The natural expansion of this research would be to evaluate the implementation of environmental accounting audits and to measure the environmental awareness at different levels of employers in the construction industry. Moreover, an investigation is required to evaluate the existence of internal environmental audit teams in industrial organizations. 


\section{REFERENCES}

[1] Aerts, W., Cormier, D. (2009): Media legitimacy and corporate environmental communication. - Accounting, Organizations and Society 34(1): 1-27.

[2] Bansal, P., Clelland, I. (2004): Talking trash. Legitimacy, impression management, and unsystematic risk in the context of the natural environment. - Academy of Management Journal 47(1): 93-103.

[3] Bansal, P., Roth, K. (2000): Why companies go green. a model of ecological responsiveness. - Academy of Management Journal 43(4): 717-736.

[4] Barrett, S. (2005): Chapter 28 The theory of international environmental agreements. Handbook of Environmental Economics 3: 1457-1516.

[5] Brønn, P. S., Vidaver-Cohen, D. (2009): Corporate motives for social initiative. legitimacy, sustainability, or the bottom line? - Journal of Business Ethics 87(S1): 91109.

[6] Burchell, J., Cook, J. (2008): Stakeholder dialogue and organisational learning. Changing relationships between companies and NGOs. - Business Ethics: A European Review 17(1): 35-46.

[7] CLC (1969): International convention on civil liability for oil pollution damage. - CLC, Brussels.

[8] Contractor Classification Agency, Ministry of Municipal and Rural Affairs (2018): Number of Contarctors Classsified by Field, Saudi Arabia. - Ministry of Municipal and Rural Affairs, Riyadh.

[9] Deegan, C. (2002): Introduction: The legitimising effect of social and environmental disclosures - a theoretical foundation. - Accounting, Auditing \& Accountability Journal 15(3): 282-311.

[10] Eckersley, P. (2016): Cities and climate change. How historical legacies shape policymaking in English and German municipalities. - Politics 37(2): 151-166.

[11] Fernandes Rei, F. C. (2018): International environmental law and global environmental governance: southern influences. - Veredas do Direito 15(32): 143-165.

[12] Field, C. B. (2014): Climate Change 2014: Impacts, Adaptation, and Vulnerability. Cambridge University Press, Cambridge.

[13] Fine, J. D., Owen, D. (2005): Technocracy and democracy: Conflicts between models and participation in environmental law and planning. - Hastings Law Journal 56(5): 901.

[14] Freeman, J., Farber, D. A. (2005): Thirty-fourth annual administrative law issue modular environmental regulation. - Duke Law Journal 54(4): 795-912.

[15] Hallett, J. (2002): Climate change 2001: The scientific basis. Edited by J. T. Houghton, Y. Ding, D. J. Griggs, N. Noguer, P. J. van der Linden, D. Xiaosu, K. Maskell and C. A. Johnson. Contribution of Working Group I to the Third Assessment Report of the Intergovernmental Panel on Climate Change, Cambridge University Press, Cambridge. 2001. 881 pp. ISBN 052101495 6. - Quarterly Journal of the Royal Meteorological Society 128(581): 1038-1039.

[16] Hasseldine, J., Salama, A. I., Toms, J. S. (2005): Quantity versus quality. The impact of environmental disclosures on the reputations of UK Plcs. - The British Accounting Review 37(2): 231-248.

[17] Horn, H., Mavroidis, P. C. (2014): Multilateral environmental agreements in the WTO. Silence speaks volumes. - International Journal of Economic Theory 10(1): 147-166.

[18] Howarth, W. (2011): Diffuse water pollution and diffuse environmental laws. - Journal of Environmental Law 23(1): 129-141.

[19] Hunter, T., Bansal, P. (2007): How Standard is standardized MNC global environmental communication? - Journal of Business Ethics 71(2): 135-147.

[20] Hutchins, J., Sinha, M., Nandan, S. (2019): The sustainability route to corporate legitimacy. - Journal of Global Scholars of Marketing Science 29(1): 15-24.

[21] IBM SPSS Statistics (2015): IBM SPSS Statistics. - IBM, Armonk, NY. 
[22] Jordan, S. J., Hayes, S. E., Yoskowitz, D., Smith, L. M., Summers, J. K., Russell, M., Benson, W. H. (2010): Accounting for natural resources and environmental sustainability: linking ecosystem services to human well-being. - Environmental Science \& Technology 44(5): 1530-1536.

[23] Kelemen, R. D., Knievel, T. (2015): The United States, the European Union, and international environmental law: The domestic dimensions of green diplomacy. - ICONInternational Journal of Constitutional Law 13(4): 945-965.

[24] Kellenberg, D., Levinson, A. (2014): Waste of effort? International environmental agreements. - Journal of the Association of Environmental and Resource Economists 1(1/2): 135-169.

[25] Millimet, D. L., Roy, J. (2015): Multilateral environmental agreements and the WTO. Economics Letters 134): 20-23.

[26] OILPOL 1954 (1958): International convention for the prevention of pollution of the sea by oil, London, May 12, 1954, [Gt. Brit. Parliament. Papers by command] Cmnd 595. H. M. Stationery Off., London.

[27] Okereke, C. (2007): An exploration of motivations, drivers and barriers to carbon management. - European Management Journal 25(6): 475-486.

[28] Palazzo, G., Scherer, A. G. (2006): Corporate legitimacy as deliberation. A communicative framework. - Journal of Business Ethics 66(1): 71-88.

[29] Paudel, S., Elmtiri, M., Kling, W. L., Le Corre, O., Lacarrière, B. (2014): Pseudo dynamic transitional modeling of building heating energy demand using artificial neural network. - Energy and Buildings 70): 81-93.

[30] Pavoni, R., Piselli, D. (2016): The sustainable development goals and international environmental law: normative value and challenges for implementation. - Veredas do Direito 13(26): 13-60.

[31] Sand, P.H. (2012): The Evolution of Transnational Environmental Law: Four Cases in Historical Perspective. - Transnational Environmental Law 1 (1):183-198.

[32] Solomon, A., Lewis, L. (2002): Incentives and disincentives for corporate environmental disclosure. - Business Strategy and the Environment 11(3): 154-169.

[33] Suchman, M. C. (1995): Managing legitimacy. strategic and institutional approaches. Academy of Management Review 20(3): 571-610.

[34] The General Authority of Meteorology and Environmental Protection (ed.) (2001): General Environmental Regulations and Rules for Implementation. 1st Ed. - Saudi Government, Saudi Arabia.

[35] To, W. M., Lee, P. (2014): Diffusion of ISO 14001 environmental management system. Global, regional and country-level analyses. - Journal of Cleaner Production 66): 489498.

[36] Toms, J. S. (2002): Firm resources, quality signals and the determinants of corporate environmental reputation. Some UK evidence. - The British Accounting Review 34(3): 257-282.

[37] Van Kempen, J. J. H. (2012): Countering the obscurity of obligations in European environmental law: an analysis of Article 4 of the European Water Framework Directive. - Journal of Environmental Law 24(3): 499-533.

[38] Van Zeben, J. (2014): Subsidiarity in European environmental law: a competence allocation approach. - Harvard Environmental Law Review 38(2): 415-464.

[39] Villiers, C. de, van Staden, C. J. (2006): Can less environmental disclosure have a legitimising effect? Evidence from Africa. - Accounting, Organizations and Society 31(8): 763-781.

[40] Wang, A. L. (2013): The search for sustainable legitimacy: environmental law and bureaucracy in China. - Harvard Environmental Law Review 37(2): 365-440.

[41] White, M. J., Hunter, L. M. (2009): Public perception of environmental issues in a developing setting: environmental concern in coastal Ghana. - Social Science Quarterly 9(4): 960-982. 
[42] Williamson, D., Lynch-Wood, G., Ramsay, J. (2006): Drivers of environmental behaviour in manufacturing SMEs and the implications for CSR. - Journal of Business Ethics 67(3): 317-330.

[43] Yang, T., Percival, R. V. (2009): The emergence of global environmental law. - Ecology Law Quarterly 36(3): 615-664. 